Alexandra M.M. Robert, Jean Letouzey, Mohammad A. Kavoosi, Sharham Sherkati, Carla Müller, Jaume Vergés, Abdollah Aghababaei,

Structural evolution of the Kopeh Dagh fold-and-thrust belt (NE Iran) and interactions with the South Caspian Sea Basin and Amu Darya Basin,

Marine and Petroleum Geology, Volume 57, November 2014, Pages 68-87, ISSN 0264-8172, http://dx.doi.org/10.1016/j.marpetgeo.2014.05.002.

\title{
*Manuscript
}

Click here to view linked References

\section{Structural evolution of the Kopet Dagh fold-and-thrust belt (NE Iran) and interactions with the South Caspian Sea Basin and Amu Darya Basin}

\author{
Alexandra M. M. Roberta, ${ }^{\mathrm{a},}$,Jean Letouzey ${ }^{\mathrm{c}}$, Mohammad A. Kavoosi ${ }^{\mathrm{d}}$, \\ Sharham Sherkatid ${ }^{\text {, }}$ Carla Müller ${ }^{c}$, Jaume Vergés ${ }^{b}$, Abdullah Agababai $^{\mathrm{d}}$ \\ ${ }^{a}$ Géosciences Environnement Toulouse (GET), Observatoire de Midi-Pyrénées, \\ Université de Toulouse, CNRS, IRD, F-31400 Toulouse, France, \\ (alexandra.robert@get.obs-mip.fr) \\ ${ }^{b}$ Group of Dynamics of the Lithosphere (GDL), Institute of Earth Sciences Jaume \\ Almera, ICTJA-CSIC, c Lluís Solé $i$ Sabaris s/n, 08028 Barcelona, Spain \\ ${ }^{c}$ Institut des Sciences de la Terre Paris (iSTeP), Sorbonne Universités, UPMC Univ \\ Paris 06, UMR 7193, F-75005 Paris, France \\ ${ }^{d}$ National Iranian Oil Company (NIOC), Exploration, Yaghma alley, Jomhuri ave,
} Tehran, Iran

\begin{abstract}
We present a detailed stratigraphic and structural study of the Kopet Dagh fold-and-thrust belt in NE Iran, which is an investigation of the complex polyphased tectonic history of this belt and its links with the adjacent South Caspian Sea and Amu Darya basins. Based on numerous field surveys, a large amount of 2D and 3D seismic data, borehole data and more than 150 new biostratigaphic datings, a new detailed biostratigraphic chart and 4 main regional cross-sections illustrate the importance of lateral facies variations and structural inheritance in the present-day structure of the belt.

After the Cimmerian orogeny corresponding to the closure of the Paleotethys Ocean in Late Triassic-Early Jurassic times, a post-collisional rifting event was associated with the deposition of one of the main source rocks of the Kopet Dagh and the Amu Darya Basin (Kashafrud Formation). Following
\end{abstract}


this rifting event, over $7 \mathrm{~km}$ of sediments were accumulated until the Tertiary above a regional post-Triassic unconformity. The occurrence of local uplifts during the Late Cretaceous-Early Paleocene is interpreted as a consequence of regional-scale modication of plate-slab coupling in the Neotethys subduction zone. The structures associated with the Late Eocene/Oligocene folding phase are sealed in the western part of the belt by a major Eocene-Oligocene unconformity at the base of the thick sedimentary series belonging to the South Caspian Sea Basin. The rapid subsidence of the South Caspian Sea Basin is probably related to syn-compressional downward flexure of the resistant basement basin at the onset of the Alpine phase. In the eastern part of the Kopet Dagh, this deformation is characterized by Middle Jurassic graben inversion with evidences of forced-folding, short-cuts and present-day slip partitioning, and as well by larger scale basement uplift. In contrast, the northwestern part of the belt shows thrust faults involving basement and fault-propagation folds within the sedimentary sequence. The Kopet Dagh presents an arcuate shape that follows the Paleotethys suture zone, which emphasizes the importance of the structural inheritance and inversion processes in the present-day structures. Finally, a change from a mostly dip-slip to a mostly strike-slip tectonics occurred during the Pliocene within the Kopet Dagh as a consequence of a major tectonic reorganization in NE Iran.

Keywords: Kopet Dagh, Amu Darya Basin, South Caspian Sea Basin, Graben Inversion, Structural Geology, Seismic Sections 


\section{Introduction}

2 Iran extended deformed zone is surrounded by the Turan Plate to the NE, 3 which is part of stable Eurasia and by the Arabia Plate to the SW (Figure 4 1a). Indeed, the Iranian geology is dominated by the long-standing conver5 gence history between Eurasia and Gondwanan-derived terranes as indicated 6 by numerous ophiolitic belts, fold-and-thrusts belts and resistant blocks that 7 remain within the deformation zone. Two major compressional events, as 8 a consequence of oceanic closures are described in Iran: (1) the Cimmerian 9 orogeny, which is related to the closure of the Paleotethys Ocean and (2) 10 the Alpine orogeny as a result of the closure of the Neotethys Ocean. In 11 northeastern Iran, the Paleotethys Ocean separated the Turan Plate from 12 Central Iranian blocks whereas the Neotethys Ocean opened on the southern margin of the Central Iranian blocks during the Permian (Muttoni et al., 2009) (Figure 1a). Besides, several ophiolitic domains (Nain Baft, Sabzevar, Sistan) cross-cut Central Iran and are interpreted as remnants of small oceanic domains that were closed during Paleocene to Eocene times (Agard

17 et al., 2011).

${ }_{18}$ In northeastern Iran, the Paleotethys suture zone corresponds to the bound19 ary between the Kopet Dagh fold-and-thrust belt to the NE, and the east20 ern prolongation of the Alborz range to the SW (Figure 1a). Remnants of 21 the Paleotethys Ocean are located within the Binalud Mountains where the 22 Cimmerian event is characterized by a collisional type event during the Late 23 Triassic/Early Jurassic (Sheikholeslami and Kouhpeym, 2012). Following 24 this collision, the Kopet Dagh Basin was deposited on the southern margin 25 of the Turan Plate from the Jurassic to the Tertiary (Brunet et al., 2003). 
This basin was inverted during the Tertiary, because of the NE oriented convergence between Central Iran and Turan plates. Several authors studied the metamorphism and the deformation associated with the closure of the Paleotethys, but there are still few data on the structural and sedimentologic evolution within the Kopet Dagh after the Cimmerian orogeny. Understanding the evolution of the Kopet Dagh is important, because of its direct link with the Amu Darya Basin to the NE and with the South Caspian Sea Basin where lithological and structural information on Mesozoic rocks are rare, because of the important thickness of Tertiary sediments. The Amu Darya Basin is a large basin that subsided during the Mesozoic after the closure of the Paleotethys Ocean and which is located in Turkmenistan and Uzbekistan extending southwestward into Iran and southeastward into Afghanistan (Ulmishek, 2004). This basin is a highly productive oil and gas province which contains numerous giant gas fields such as Dauletabad, Yoloten, Shaltyk, Bayram-Ali or Achak (see location on Figure 1b) (Ulmishek, 2004). Two important gas fields are located to the East of the Kopet Dagh: the Khangiran and the Gonbadli, which produce from the Upper Jurassic carbonates (Mozduran Formation) and the Lower Cretaceous siliciclastics (Shurijeh Formation) (Afshar-Harb, 1979; Aghanabati, 2004; Kavoosi et al., 2009a). These two gas fields are located in anticlinal traps (Moussavi-Harami and Brenner, 1992) that include the $35 \mathrm{~km}$-wide Khangiran anticline. The volume of recoverable gas reserves at Khangiran was estimated at 16.9 trillion cubic feet by Iran Oil Ministry (2000) and the gas is piped from reneries to cities in northeastern Iran. The main source rocks are considered to be the Middle Jurassic shales and carbonates of the Chaman Bid Formation and the Upper 

59 Iranian region.

60

Bajocian to Bathonian mudstones of the Kashafrud Formation.

In this article, we will focus on the structural evolution of Kopet Dagh foldand-thrust belt, with new stratigraphic and structural data, in order to set up the sedimentologic and structural evolution of the belt since the closure of the Paleotethys Ocean in Late Triassic/Lower Jurassic times. We will discuss the links between deformation in the Kopet Dagh and sedimentation in the adjacent Amu Darya and South Caspian Sea basins, which constitute an important contribution to unravel the structural evolution of the northern

\section{Geological settings}

\subsection{Location and Morphology}

This range marks the northern limit of the Alpine-Himalayan orogeny in northeastern Iran and it also corresponds to the morphological boundary between Turkmenistan and Iran which separates the Turan Plate, part of stable Eurasia, from Central Iran over more than $600 \mathrm{~km}$ (Figure 1a.).The Kopet Dagh belt is an intra continental range which can be divided into three different parts, (1) the northwestern part that is oriented N90, (2) the northern part which mostly belongs to Turkmenistan and (3) the eastern part which is N120 oriented (Figure 2). Different authors do not agree about the extent of the Kopet Dagh belt and we will use the largest extent of the belt and distinguish 3 main structural zones. The relief associated with the belt dies out southeastwards towards Afghanistan, indicating the lack or small amount of recent active tectonics in this part of the belt. The Kopet Dagh range presents moderate elevations reaching $3120 \mathrm{~m}$ high in the southeastern 
98 Kopet Dagh Basin was deposited after the Cimmerian orogeny (Garzanti and

99 Gaetani, 2002) and more than $7 \mathrm{~km}$ of post-Triassic sediments were accumu- 
lated in this basin (Moussavi-Harami and Brenner, 1992). The onset of uplift within the Kopet Dagh is considered to have begun after 30Ma (Berberian and King, 1981; Golonka, 2004; Hollingsworth et al., 2010). From a geological point of view, (Lyberis and Manby, 1999) proposed that the inversion of the margin occurred during the Late Miocene as a response to the NorthSouth convergence between Iran and Turan plates. However, post-Eocene sediments of the range are not well dated and more precise studies concerning the timing of inversion of the margin are needed. According to geodetic and geological data, between 4 and $11 \mathrm{~mm} . \mathrm{yr}^{-1}$ of the present day northward Arabia-Eurasia convergence is accommodated in northeastern Iran (Vernant et al., 2004; Reilinger et al., 2006; Shabanian et al., 2009a, e.g.). The northwestern strike of the convergence involves thrust faulting and minor left lateral strike-slip in the northwestern part of the belt and mainly right-lateral strike-slip faulting in the eastern part of the range (Figure 2). This observation is confirmed by the earthquakes focal mechanisms that show thrusting to the West and strike-slip faulting with some thrusting to the east (Figure 2). Furthermore, in the eastern part, recent strike-slip faulting across the belt is responsible of the dissection of the folds that can be observed to the East of Bojnurd city.

According to geomorphologic data and datings, Shabanian et al. (2009b, 2012) inferred that the important lateral motion recorded within the Kopet Dagh belt should not have started before the Early Pliocene ( $\sim 4 \mathrm{Ma}$ ) which corresponds to the commonly proposed widespread reorganization of the tectonic deformation in the Arabia/Eurasia collision zone (Axen et al., 2001; 
Allen et al., 2004; Copley and Jackson, 2006, e.g.). In contrast, Hollingsworth et al. (2008) propose that main strike-slip motion within the Kopet Dagh could have be initiated earlier, at $\sim 10 \mathrm{Ma}$, and that the initiation of this lateral motion could be related to the westward extrusion of the South Caspian Sea Basin relative to Central Iran and Eurasia.

Nevertheless, especially in the eastern part of the belt, fold axes and strikes of the major tectonics features likely suggest a SW-NE oriented shortening, that probably reflects the tectonic settings before the reorganization of the tectonics deformation across the belt that we considered to have occurred at $\sim 4 \mathrm{Ma}$ as suggested by Shabanian et al. (2009b, 2012).

\section{Stratigraphic description}

We present our sedimentologic and biostratigraphic study that results from widespread and numerous field surveys performed by the NIOC team including 3 common field missions. Before this contribution, the stratigraphy in the Kopet Dagh was essentially based on facies recognition and correlation that resulted in differentiation of numerous formations, mainly according to lithological criteria. In this study, a widespread biostratigraphic study of the pelagic facies that have been correlated with precise lithological descriptions including more than 150 datings is presented, which allows us to propose a new stratigraphic chart for the Kopet Dagh and the surroundings basins (Figure 3). Our biostratigraphy is based on investigation of calcareous nannofossils. Age determination of the Mesozoic was performed from publications of Thierstein (1976) and Perch-Nielsen (1985) and we used the zonation given by Martini (1971) for the Cenozoic. Our results have been synthesized in the 
stratigraphic chart (Figure 3) and are also presented in Table 1 that indicates location of the main dated samples and names of the nannofossils.

In this section, we will describe the detailed stratigraphy of the Kopet Dagh region, from the oldest outcropping rocks to the Tertiary continental sediments.

\subsection{Devonian to Upper Triassic: before the deposition of the Kopet Dagh} Basin

The oldest rocks outcropping in the Kopet Dagh fold-and-thrust belt are Devonian to Lower Carboniferous (Lyberis et al., 1998) and they are mostly outcropping within the Aghdarband erosional window, in the eastern part of the belt (Ruttner, 1991). Most of the sediments in this erosional window are Triassic in age and are strongly deformed as a consequence of the closure of the Paleotethys Ocean during the Cimmerian orogeny. Several unconformities between the different series are observed.

The Upper Devonian series are constituted at their base by dark grey thinly bedded volcanoclastics, shales and turbiditic sandstones. These series are overlain by dark green volcanoclastic sediments, with some limestone layers. The Lower Carboniferous is characterized by white limestones of about 200 $\mathrm{m}$ thickness with the occurrence of some diabase dykes. The ?Late Permian to Lower Triassic molassic type rocks are composed of some red quartzitic sandstones and siltstones, with intercalated conglomerates that include pebbles of quartz, pink colored granites, radiolarites and Carboniferous to Late Permian limestones. These series present a thickness up to $500 \mathrm{~m}$.

The Triassic series of the Aghdarband erosional windows can be distinguished in 4 main units: the three lowermost units that comprise an important 
volcanic component were deposited before the Middle Cimmerian orogeny, whereas the fourth unit indicates deltaic conditions of deposition and results from the erosion of the relief formed during the Cimmerian orogeny (Ruttner, 1991). In this study, we are not differentiating the different stages of the Cimmerian orogeny.

The Lower Triassic (T1) is characterized by red shales and sandstones with conglomerates including pebbles of quartz and red granites. Some tuffaceous shales are observed in the upper part, which are overlain by limestones dated as a Lower Triassic from the presence of ammonites. The Lower Triassic is also separated from the underlying sequence by a tectonic contact. The Middle Triassic (T2) sequence starts with a conglomerate including only pebbles of the underlying limestone and is followed by volcanoclastic sandstone, and tuffaceous shales in the upper part. It is dated by two fossil horizons with abundant crinoids and ammonites, assigned to Landinian to Lower Carnian in age. The uppermost part of the Middle Triassic (T3) is marked by hard volcanoclastic sandstones and conglomerates. The Upper Triassic (T4) sequence presents an unconformity at its base and starts with some sandstone without volcanic components and rich in coal layers on top of which there is some shale. These deposits, named the Miankuhi Formation, are dated by plant fragments as Upper Carnian and Lower Norian. Thedark shales and ne-grained sandstones of the coal bearing Miankuhi Formation may represent an equivalent to the lower part of the Shemshak Group (Taheri et al., 2009; Wilmsen et al., 2009). Indeed, the lack of an equivalent to the widespread across the Iran Plate, Upper Triassic/Middle Jurassic Shemshak Group has been interpreted as a consequence of a period of emergence of the Turan 
area (Lyberis et al., 1998). The Miankuhi Formation is intruded by coarsecrystalline leucogranites (Torbat-e-Jam Granite) that have been dated at 217 +/- 1.7 Ma by (Zanchetta et al., 2013).

\subsection{Middle Jurassic: Sedimentation during the rifting following the Cimme- rian orogeny (Kashafrud Formation)}

Following the closure of the Paleotethys, the so-called Kopet Dagh Basin was deposited from the Middle Jurassic to the Tertiary and it corresponds to the southern border of the Amu Darya Basin. The sedimentation began with deposition of the Middle Jurassic Kashafrud Formation, which rests unconformably on folded Triassic or older rocks (Taheri et al., 2009). The Kashafrud Formation comprises $300 \mathrm{~m}$ to more than $2500 \mathrm{~m}$ of deep-marine siliciclastic strata (Poursoltani et al., 2007; Taheri et al., 2009). Furthermore, it could be either very thick, or absent above crest blocks or paleohighs. The Middle Jurassic Kashafrud Formation is generally conglomeratic at its base and consists of thick siltstones, sandstones and shales units. Where the whole formation is observed, the base presents more shaley facies and the top of the formation is characterized by shallower conditions of deposition as indicated by channelized sandstones typical of deltaic facies. Our biostratigraphic data indicate an Aalenian to Bajocian age for this formation (Figure 3 and Table 1). This sequence was deposited in a rift system as indicated by the rapid facies and thickness variations (Kavoosi et al., 2009a). Some authors argue a direct link during the deposition of the Kashafrud Formation between the Kopet Dagh Basin and the Neotethys Ocean (Poursoltani et al., 2007), whereas others proposed a rift basin model, which implies a direct relationship with the South Caspian Basin further West, rather than a link with the 
Neotethys Ocean (Taheri et al., 2009).

\subsection{Upper Jurassic (Chaman Bid and Mozduran Formations)}

In the western part of the basin, the Kashafrud Formation is overlain by the Upper Bajocian to Tithonian Chaman Bid Formation (Kalantari, 1969), which mostly consists of alternations of grey shales and marly limestones. Main deposition environments of the Chaman Bid Formation are on the slope of a carbonate platform and in the adjacent basin (Majadifard, 2003). In contrast, towards the East, the Kashafrud Formation is overlain by the Upper Jurassic Mozduran Formation (Taheri et al., 2009), which is the main gas reservoir in the Kopet Dagh range. The Mozduran Formation is a well-bedded limestone in which several reefs systems have been observed (Figure 4). Its facies varies towards the East to siliciclastic sediments. Furthermore, the thickness of the Mozduran Formation varies from $200 \mathrm{~m}$, to $800 \mathrm{~m}$ in the Khangiran gas eld and up to over $1400 \mathrm{~m}$ in the central part of the belt (Afshar-Harb, 1979). The sharp and sudden lateral lithological and thickness variations of the Mozduran Formation are interpreted as related to the presence of paleohighs within the basin after the Middle Jurassic rifting in the Kopet Dagh Basin (Kavoosi et al., 2009b). The Mozduran Formation is overlain by Cretaceous sediments, which are divided into 10 different formations (Shurijeh, Zard, Tirgan, Sarchashmeh, Sanganeh, Aitamir, Abderaz, Abtalkh, Neyzar and Kalat) and associated with a thickness up to $4000 \mathrm{~m}$ thick in the western part of the basin (Afshar-Harb, 1979). Emami et al. (2004) suggested that the late Cimmerian tectonic phase resulted in widespread Late Jurassic-Early Cretaceous regression, leading to deposition of the Lower Cretaceous continental siliciclastics and evaporites 
of the Shurijeh Formation.

\subsection{Lower Cretaceous, Neocomian (Shurijeh and Zard Formations)}

The Lower Cretaceous Shurijeh Formation consists of red-bedded siliciclastic sediments (sandstone, siltstone and conglomerates that are reservoir rocks) overlain by limestones that present increasing thickness from the eastern part towards the central part of the belt. The upper part of the Lower Cretaceous Shurijeh Formation consists of gypsum/anhydrite deposits that were deposited in uvial to tidal at depositional settings under arid conditions as a consequence of the major regression of the sea that occurred in the Jurassic/Cretaceous transition (Moussavi-Harami and Brenner, 1990; MoussaviHarami et al., 2009). These evaporite levels make the seal for the basal Shurijeh Formation (secondary reservoir for gas in the Kopet Dagh range) and the Mozduran Formations. The thickness of the Shurijeh Formation ranges from $100 \mathrm{~m}$ above the paleohigh to about $1000 \mathrm{~m}$ thick (Afshar-Harb, 1979). Towards the NW, the Shurijeh Formation thickness decreases until being completely replaced by the Zard Formation, which mainly consists of marine marls, calcareous shale with some sandstone beds (Afshar-Harb, 1979). Our biostratigraphic results indicate a Berriasianage for this formation, but some outcrops indicate a minimum Late Kimmeridgian age (Jamali et al., 2011), and a Tithonian age was assigned to the Shurijeh Formation for its western most outcrops. 


\subsection{Lower Cretaceous, Aptian-Albian (Tirgan, Sarchashmeh and Sanganeh Formations)}

The deposition of the continental Shurijeh Formation is followed by shallow marine sedimentation characterized by the deposition of the marls and orbitolinids rich limestone Tirgan Formation with a thickness up to $600 \mathrm{~m}$ to the West of the belt. The age of this series is Barremian and the nannofossils are often strongly recrystallized and fragmented. The Sarchashmeh Formation (about 150-250m thick) conformably overly the calcareous Tirgan Formation and consists of two members: the lowest uniform grey marl unit and the upper layer that consists of an alternance of shale and limestone. The upper unit contains lumachelle layers deposited in at channels above which about $1000 \mathrm{~m}$ thickness of marls were deposited. These thick marls become richer in ne grained sandstone layers in the upper part which corresponds to the dark grey shales of the Sanganeh Formation. From our biostratigraphic study, a Late Barremian to Aptian age is proposed for the Sarchachmeh Formation and the Sanganeh Formation appears to be Albian in age. These results disagree with Raisossadat and Shokri (2011) that proposed a Late Barremian to Aptian for these 2 formations but we were able to date short marine incursions as Late Albian in the Sanganeh Formation (Table 1).

\subsection{Upper Cretaceous (Aitamir, Abderaz, Abtalkh and Kalat Formations)}

The Aitamir Formation is a mudstone that grades upwards to a lower glauconitic sandstone unit with cross-stratications, hummocky cross-stratications and ripple marks, to a unit of mudstone intercalated with sandstone beds (Sharafi et al., 2012). This formation corresponds to shallow open-marine environment and its upper surface is delimited by a hiatus and local erosion 
that is the first main hiatus in the Cretaceous sedimentation recorded in the Kopet Dagh range. This formation is barren of nannofossils which do not allow us to propose an age from biostratigraphy, but it is considered as Late Albian to Cenomanian (Sharafi et al., 2012). There is an important hiatus during the Turonian. Overlying this erosional surface, the Abderaz Formation is mostly made up of calcareous and marly shales (Allameh et al., 2010). Its thickness ranges between 200 and $400 \mathrm{~m}$ to the East of the Kopet Dagh and decreases towards the western part of the belt (Afshar-Harb, 1979). From our biostratigraphy study, a Late Santonian age was determined for the Abderaz Formation but the nannofossils are often strongly recrystallized and broken within the marl intercalations. According to a study based on ostracods, the sedimentation is considered to have taken place in a shallow open marine environment with warm climate conditions from the Late Turonian to the Early Santonian (Allameh et al., 2010).

The Abtalkh Formation is well developed in the eastern Kopet Dagh and has an almost uniform lithology consisting of calcareous shales with some lumachelle rich limestone beds near the top and with locally some small rudist-patch reefs. It presents a constant thickness of 700-800 m (AfsharHarb, 1979). Our biostratigraphic study suggests Campanian ages for this formation. In the western part of the belt, the Abtalkh Formation is not developed and the Abderaz Formation is directly overlain by the Kalat Formation. In contrast, to the East of the belt, the upper part of the Abtalkh Formation is characterized by a progressive transition to the Neyzar Formation which is mostly composed of glauconite and clays with some sandstone in the upper levels indicating a shallow marine condition of sedimentation. 
The transition between the Neyzar Formation to the Kalat transition is progressive (Shahidi, 2008). The Kalat Formation is a widespread unit in the whole Kopet Dagh region and consists of a bioclastic limestone and carbonate buildups with subordinate sandstone beds observed only in the eastern part of the region (Afshar-Harb, 1979). This formation has been recently dated as Upper Campanian to Maastrichtian (Shahidi, 2008) and our biostratigraphic results indicate a Campanian age, but it was not possible to conrm the Maastrichtianage. The Kalat Formation consists of marls partly rich in gastropods and recifal limestones with rudists or algae, must have been deposited in a shallow shelf environment with a connection with the open sea (Afshar-Harb, 1979). The upper part of the Kalat Formation is marked by an erosional surface that is associated with the second general hiatus of sedimentation in the region.

\subsection{Paleogene (Pestehleigh, Chehel Kaman and Khangiran Formations)}

The transition between the Upper Campanian and the Paleocene is characterized by an increase of ne grained sandstones. The Paleocene Pestehleigh Formation is predominantly represented by red continental series with sand and siltstones with some conglomeratic levels at its base. It is followed by uviodeltaic and continental red sandstones and siltstones. Some marine incursions have been observed and dated within zone NP2 in the lowermost part and within zone NP5 upwards in the section. The uppermost Paleocene (zone NP9) was determined in the Chehel Kaman Formation that consists of white carbonates. The transition to the Lower Eocene is characterized by the occurrence of some layers of grey marls and red marls. The Eocene (zones NP12-NP19) is represented by alternating limestones and marls and 
it becomes sandier within the upper part.

\subsection{Oligocene-Neogene}

On geological maps, the youngest sediments represented are indicated as Neogene in age. However, there is no published study about precise dating of these continental series or neither about the deformation affecting these series. In this article, we decided to name this formation as Oligocene-Neogene sediments. Most outcrops of the Oligocene-Neogene conglomerates and sandstones are represented as strongly discordant. Deposition of these sediments is associated with the late reactivation of the fold belt.

\subsection{Conclusions from the stratigraphic study}

Our stratigraphic descriptions, synthesis and new biostratigraphic data can be summarized as follows:

1. There is a stratigraphic gap between the Lower Carboniferous and the thick Permo-Triassic molassic type series that are in tectonic contact. This unconformity might correspond to the Hercynian orogeny.

2. Some authors argue about several tectonic phases in the Cimmerian orogeny (Eo-cimmerian and Middle Cimmerian orogenies), but because this article is focused on the post-Cimmerian history, we will not distinguish these different phases and, instead, use the term of Cimmerian orogeny.

3. The major unconformity observed within the range corresponds to the base of the Kashafrud Formation (Middle Jurassic) which corresponds to the first deposited sediments after the Cimmerian orogeny. 
4. A rifting episode occurred in the Kopet Dagh region during the Middle Jurassic. At this time, the southern part of the Amu Darya Basin was probably linked with the South Caspian Sea Basin (Brunet et al., 2003). The abrupt facies and thickness changes of the Kopet Dagh Basin fill are inferred to mark activation of several major extensional faults during deposition of the Middle Jurassic Kashafrud Formation (Lyberis and Manby, 1999; Thomas et al., 1999).

5. During the Cretaceous and the Paleogene, several hiatus are interpreted as periods of emergence and the role of tectonics during these emergent periods could be questioned. These emergent periods are indicated as local uplifts in our stratigraphic chart (Figure 3). These hiatus have previously been interpreted a consequence of distal responses to collisional events (Berberian, 1983; Lyberis and Manby, 1999). However, there is no evidence of post-Middle Jurassic rifting as previously suggested by Lyberis and Manby (1999).

6. Finally, the late reactivation of the belt is not well dated, but occurred after the deposition of the marls of the Eocene Khangiran Formation. The occurrence of continental sedimentation is related to the structural inversion that occurred after the Eocene as a consequence of the relative motion between the Iran Plate and the Turan Plate. This inversion resulted in widespread folding and thrusting of Jurassic to Tertiary sediments (Lyberis and Manby, 1999; Allen et al., 2003). This collision led to crustal shortening and right-lateral transpression which is still continuing as indicated by seismic activity (Thomas et al., 1999; Golonka, 2004) and active faulting (Hollingsworth et al., 2006, 2008, 
2010; Shabanian et al., 2009a,b, 2012). Nevertheless, the margin inversion is not well dated, because of the lack of information of the precise timing of deposition of the post-Eocene sediments that are not widely outcropping in the range.

Our new stratigraphic results have been integrated in a detailed structural study of the belt focused on 4 main regional cross-sections. The next section presents the detailed and widespread structural study that we carried out across the Kopet Dagh range.

\section{Geological cross-sections and structure of the Kopet Dagh range}

This part describes the main structures of the Kopet Dagh based on the simplified geological map (Figure 5) and on 4 regional cross-sections across the belt (Figures 6, 11, 13 and 15). These cross-sections result from numerous field surveys and our structural interpretation locally supported by $2 \mathrm{D}$ and 3D seismic lines (see location of the presented seismic lines in Figure 5). Our field work was limited to the Iranian part of the range, which explains that the coverage of our data for the frontal part of the belt are restricted to seismic data (parts that connect with the South Caspian Sea region to the West and within the Amu Darya Basin to the NE). In the eastern part, the structural style of the front of the range has been dened using borehole data plus 2D and 3D seismic sections. Towards the South Caspian Sea Basin, folded structures are buried by the thick Oligocene to Quaternary sediments and numerous seismic lines are available in this transitional zone, above the Gorgan Plain. Two of our cross-sections (Figures 6 and 11) illustrate the links between the Kopet Dagh and the Amu Darya Basin, whereas the 2 
others (Figures 13 and 15) are focused on the links between the Kopet Dagh and the South Caspian Sea Basin.

Pre-Cimmerian sediments outcrop in the Aghdarband erosional window and in some locations in the inner part of the belt. They have not yet been described in Afghanistan or in Turkmenistan. Then, there is only little and local information about the tectonic history before the Cimmerian orogeny within the Kopet Dagh. Furthermore, folds axes within the Upper Devonian to Lower Carboniferous strata are co-axial with the folds axes observed within Triassic rocks which causes diculties to unravel tectonic effects resulting from the Hercynian orogeny than the one resulting from the Cimmerian orogeny. In this article, we will focus on the post-Cimmerian structural evolution of the fold-and-thrust belt. Following the Cimmerian orogeny, an extensional regime affected the southern Amu Darya Basin during the Middle Jurassic. From the Middle Jurassic to the Tertiary, over $7 \mathrm{~km}$ of sedimentary rocks were accumulated (Afshar-Harb, 1979) and they unconformably overlay Paleozoic and Triassic rocks (Ulmishek, 2004).

The thick sedimentary sequence is deformed as large-scale folds. The main crests of the Kopet Dagh range correspond to the fold axial regions of large anticlines mostly developed in the Lower Cretaceous limestones (Tirgan Formation). In contrast, most of the valleys are located in the core of synclines occupied by less competent rocks. There is few Tertiary sediments outcropping in the range, some of them are folded and outcrop in the center of large synclines, whereas some Oligocene-Neogene conglomerates are clearly discordant (Figure 5).

In the eastern part of the belt, the observed deformation is characterized 
by oblique Middle Jurassic graben inversion with evidences of forced-folding and few short-cuts, and as well by larger scale structures involving basement. The large-scale structures present long axis those are parallel to the Main Kopet Dagh Fault. From seismic sections, several dcollement levels within the Mesozoic sequence explain numerous disharmonies, sh-tail structures in the core of the folds or triangle zones (Figures 8 and 12). The orientation of the Main Kopet Dagh Fault is interpreted as associated with the reactivation of old Paleozoic structures (Amurskiy, 1971; Maggi et al., 2000). Similar striking Paleozoic structures are observed both within the Aghdarband Erosional window (Zanchi et al., 2009; Zanchetta et al., 2013) and to the northeastern part of the Amu Darya Basin. Indeed, the Hercynian orogeny shaped structural features trending roughly WNW-ESE inside the Turan Plate as the Kyzylkum high, which marks the northeastern border of the Amu Darya Basin. The orientation of the observed structures in the northern and eastern part of the belt is directly related to the Alpine reactivation of these Paleozoic basement structures. In contrast, in the northwestern part, the belt presents an arcuate shape that follows the Paleotethys suture zone (Figure 1b). In this part, the observed structures are thrust faults involving basement and fault-propagation folds within the sedimentary sequence.

\subsection{The eastern cross-section (Aghdarband-Gonbadly section)}

The eastern cross-section is a $140 \mathrm{~km}$ long NS geological cross-section extending from the Aghdarband erosional window to the wide anticline of the Khangiran gas eld (Figure 6, see location on Figure 5). This crosssection was created using our own field observations (Figure 7) and seismic lines including 3D seismic data and borehole data (Figures 8, 9 and 10). The 
Gonbadli and Khangiran gas fields are located in the Iranian part of the Amu Darya Basin and they extend to the Turkmen gas fields. This cross-section will be described from the South to the North.

\subsubsection{To the South of the Aghdarband erosional window}

The southern boundary of the cross-section corresponds to the prolongation of the Fariman Complex, interpreted as remnants of an intra-arc or incipient back-arc basin (Zanchetta et al., 2013). The Middle Jurassic Kashafrud Formation with evidences of syn-rift normal faulting outcrops to the North of this ophiolitic complex. The occurrence of graben inversion and few shortcuts within the Middle Jurassic Kashafrud Formation are highlighted in this part of the cross-section. Towards the North, within the Kol Malek syncline, Mesozoic sediments are thinner compared to the sediments belonging to the Amu Darya Basin and they are conformably overlain by Cenozoic sediments. The Kol Malek syncline is pinched and its northern ank is overthrust by rocks belonging to the Darreh Anjir ophiolitic complex.

\subsubsection{The Aghdarband erosional window}

The basement of the South Amu Darya Basin is observed within the Aghdarband erosional window. This basement consists of sedimentary, metamorphic and igneous rocks with ages ranging from Devonian to Triassic and mostly corresponds to preserved fragments of a continental arc (Baud and Stampfli, 1989; Poursoltani et al., 2007). The erosional window corresponds to faulted and folded strata that are preserved below double verging thrusts (Figure 7). 
To the South of the window, the Darreh Anjir complex, consisting of gabbros and low metamorphosed basalts, cherts and marbles (Zanchetta et al., 2013) is thrusted on top of the northern flank of the Kol Malek syncline. The southern boundary of the complex is given by a south verging thrust which stacks the mostly mac rocks of the Darreh Anjir complex on the Late Triassic Miankuhi Formation, whereas, a thick succession of Upper Permian-Lower Triassic molassic-type sediments (conglomerates, sandstones and siltstones) overthrusts the northern boundary of the complex (Figure 7) (Zanchetta et al., 2013). Previous interpretations suggest that the Darreh Anjir complex corresponds to Paleotethys remnants (Ruttner, 1991; Alavi et al., 1997). However, a recent study suggests that this complex including both intrusive and lavas flows is, thus, remnants of a magmatic arc and related basins developed on the southern Eurasia margin, to the NE of the Paleotethys suture zone (Zanchetta et al., 2013). The Paleozoic and Lower Mesozoic sediments deformed within the Aghdarband window derived from the erosion of the Hercynian orogen (Ruttner, 1991). The faults that are affecting these sediments are laterally embedded by the Middle Jurassic Kashafrud Formation, which suggests a Cimmerian age for these faults.

Ruttner (1991) distinguished 4 members within the Triassic series: (T1) formed by limestones and conglomerates consisting of limestones pebbles, overlain by alternance of tuffaceous sandstone and limestone beds, (T2) consisting of tuff and tuffaceous sandstones with a basal conglomerate containing quartz pebbles, (T3) made of tuaceous sandstone, so-called tuff and some shales at its top and (T3a), the Miankuhi Formation which is marked by a coal horizon at its base overlain by sandstone layers. The T1, T2 and T3 
series are characterized by an important volcanic input suggesting that they derived from the erosion of a volcanic arc. To the North, the low metamorphosed molassic succession overthrusts Triassic units that are forming a large south-verging syncline marked in its central part by a narrow anticline and some coal-rich sediments of the Miankuhi Formation outcrop in the core of the syncline. The northern flank of the large syncline is bounded by another double-verging syncline presenting secondary order folds in its core. Its northern boundary is marked by several narrow strips of steeply inclined Triassic rocks that are interpreted as due to a flower structure. Indeed, towards the North, a steep vertical Cimmerian fault striking WNW-ESE with dextral strike-slip component has been described and separates the slightly deformed Triassic sediments from the more deformed Devonian and Carboniferous sediments (Zanchi et al., 2010). Devonian sediments consist of folded turbiditic series, whereas, the Carboniferous strata are white marbles with diabase intrusions. The fold axes observed in Devonian and Carboniferous sediments are coaxial with the ones observed within the Triassic, which does not allow easily distinguishing the deformation associated with the Cimmerian orogeny from the one associated with the Hercynian orogeny. To the North of the Aghdarband erosional window, the Middle Jurassic Kashafrud Formation overlay unconformably the Devonian strata.

\subsubsection{To the To the North of the Aghdarband window}

To the North of the Aghdarband window, seismic data suggest a triangle (or fish-tail) structure (Figure 8). The older than the Late Cretaceous (Campanian) series are force-folded and thrusted to the NE, whereas, the younger series (uppermost Cretaceous and Tertiary) form a wide monocline towards 
the NE. This is interpreted as a consequence of a triangle zone associated with disharmony and back-shearing within Late Cretaceous marls. During our field missions, we also observed some thrusting to the SW due to minor dcollements within the Middle or Upper Jurassic shales.

Towards the NE, the Mesozoic and Cenozoic series of the South Amu Darya Basin are imaged on the 2D and 3D seismic lines available in the Gonbadli and Khangiran gas elds area (Figures 9 and 10). Late Jurassic to Late Eocene series slightly thick away from the Aghdarband erosional window, which suggests that the region formed a persistent paleorelief during the deposition of the South Amu Darya Basin.

The seismic sections (Figure 9) supported with field evidences indicate that the Middle Jurassic Kashafrud Formation was deposited in a rift system, which is consistent with the occurrence of conglomeratic levels at the base of the formation covered by clastic deposits. Furthermore, there are important lateral variations in thickness of the Kashafrud Formation from no deposition on the crests of the blocks to several kilometers thick in the hanging wall of the normal faults. Forced folding as a consequence of the inversion of a major Middle Jurassic rift faults system is observed on seismic sections (Figure 10). Some Tertiary en echelon faults can be observed on the 3D seismic block on the top of the basement uplift shown in Figure 9a, indicating a dextral component during the Tertiary inversion along the WNW-ESE trending structures.

Some carbonate build-up and progradations within the Upper Jurassic carbonatic sequence are observed (indicated by the black arrow in Figure 10 similar to the ones we observed in the field (Figure 4b). 


\subsubsection{Summary of the Aghdarband-Gonbadly cross-section}

The Aghdarband-Gonbadly cross-section shows a major basement inversion that affects the southern border of the Amu Darya Basin. A progressive thinning of the Jurassic and Cretaceous series of the basin towards the NE, as well as the occurrence of more pelagic facies to the North and more continental facies towards the Aghdarband erosional window, suggest that the region of the erosional window formed a persistent paleorelief during the deposition of the series of the basin. Deposition of the Middle Jurassic Kashafrud Formation occurred during active rifting as highlighted by numerous normal offsets shifting the base of this formation. Locally, the rift system has been inverted as suggested by the observation of forced-folding within the Upper series, which is attributed to the Tertiary inversion of the range. This late tectonic inversion is associated with an important strike-slip component, and with the development of growth strata within the Tertiary sediments. There is little information in the Turkmen part of this cross-section but several gas fields are producing from the clastic series of the Early Cretaceous Shurijeh Formation or from the reefal carbonates of the Late Jurassic Mozduran Formation capped by the Late Jurassic-Early Cretaceous evaporites and salt layers within the Amu Darya Basin.

\subsection{Darre Gaz cross-section}

The 160 km-long DarreGaz cross-section is passing through the Darre Gaz syncline where the Tertiary series are the thickest observed within the range (Figure 11). This cross-section highlights the front of the Kopet Dagh and it is passing through the area where there are numerous recent strike-slip faults that cross-cut the structures. Along this cross-section, the sedimentary series 
are thicker than along the Aghdarband-Gonbadly cross-section and presents uplifted deeper facies. For this cross-section, seismic sections only exist in the Darre Gaz region. Thicknesses of the formations were estimated according to field observations, seismic data and satellite imaging, because of the lack of borehole data. As for the eastern cross-section, the basement is also implied in the deformation and several dcollement levels within the Mesozoic series are observed. This cross-section will be described from the SW to the NE.

\subsubsection{Description of the Darre Gaz cross-section}

In the southwestern part of the cross-section, the folded structures present a wavelength of about $12 \mathrm{~km}$ and they are cut by several strike-slip faults. We infer that the folding of the series could be associated with the inversion of Middle Jurassic grabens. The strike-slip faults affect the discordant Tertiary series and are associated with the most recent tectonics affecting this belt.

The seismic section shown in Figure 12 is located along the structural section.

It highlights an important disharmony between deep and surface structures, with several dcollements levels within the thick Cretaceous series. Main dcollement levels are located within the Kashafrud Formation, within the evaporitic levels of the Surijeh Formation and within the thick marly Sarchashmeh and Sanganeh formations. Some structures are outcropping laterally, such as the narrow reverse fold affecting the Barremian limestones of the Tirgan Formation. Finally, the northeastern part of the cross-section corresponds to the Zarrineh Kuh anticline that forms the front of the Kopet Dagh range. Seismic data (Figure 12) show 2 anticlines: (1) the shallower anticline that affects Cretaceous and Paleocene levels and that is narrower 
than (2) the deeper one, in which the Jurassic series are affected by larger wavelength forced-folding. There are no seismic data along the section crossing the Zarrineh Kuh anticline but, seismic profiles of its southwestern flank highlight the important disharmony between shallow and deep structures.

\subsubsection{Summary of the Darre Gaz cross-section}

The Darre Gaz cross-section highlights the importance of forced-folding affecting the basement and overlain by shorter wavelength folds detached along several decollement levels. Surrounding seismic sections show that the dcollement level of the frontal fold is located within the Lower Cretaceous, probably within the evaporitic levels. This cross-section attests of the important partitioning of the recent deformation across the belt: thrusts are located in the frontal part of the range as highlighted by compressional focal mechanisms whereas mostly strike-slip deformation is now affecting the internal parts of the range.

\subsection{Western Kopet Dagh cross-section}

This $90 \mathrm{~km}$-long regional cross-section (Figure 13) cuts across the western branch of the Kopet Dagh range, from the internal zone until the South Caspian Sea Basin. It is a dog-leg type cross-section based on available outcrops and it presents typical structures and unconformities characterizing this area. Thickness variations have been observed on the field. At large scale, this section shows the uplift and erosion of the inner part of the Kopet Dagh as a consequence of several periods of uplift and/or folding. The southwestern part of this section corresponds to the inner part of the belt, where several basement thrusts are observed and where Paleozoic and Mesozoic for- 
mations outcrops at several locations. In this area, the folds of the western part of the Kopet Dagh are oriented SW-NE (Figure 5) and plunge to the SW in the Gorgan Plain below the sediments of the South Caspian Sea Basin.

\subsubsection{Description of the western Kopet Dagh cross-section}

We will describe this cross-section from the internal zone, close to the Late Triassic/Early Jurassic Paleotethys suture zone towards the Gorgan Plain corresponding to the eastern prolongation of the South Caspian Sea Basin. The large wavelength structures present a SE vergence until Balkor syncline (Figure 13). In contrast, the structures that plunge beneath the Gorgan Plain present an opposite NW vergence.

The southeastern part of the cross-section corresponds to a large SE-verging anticline (Figure 13) formed by the series from Paleozoic to Eocene in age. On top of the Paleozoic, Triassic series (shales, grey-yellow dolomites and basalts) are outcropping and unconformably overlain by a conglomeratic level corresponding to the base of the Middle Jurassic Kashafrud Formation. The Kashafrud Formation presents a fan geometry and its thickness is locally up to $2500 \mathrm{~m}$ in the deeper parts of this rift structure (Figure 14).

The Middle Jurassic Kashafrud Formation overlays lower series (Paleozoic or Triassic series) and is unconformably covered by the marls of the Upper Jurassic Chaman Bid Formation that could locally directly overly the Triassic strata. This erosion on top of the Kashafrud Formation was also observed on some seismic lines in the eastern part of the Kopet Dagh (Kavoosi et al., 2009b). Above a thin marly and clastic level, the Lower Cretaceous Tirgan limestone reaches around $450 \mathrm{~m}$ of thickness. On the top of the Tirgan Formation, there are numerous sedimentation lacunas and it is locally covered 
by the very thin Sarchashmeh Formation or by the Abderaz Formation. The whole Upper Cretaceous series do not reach $400 \mathrm{~m}$ of thickness and they are overlain by the reddish series of the Paleocene. There is an important thinning of the Mesozoic series and in particularly of the Lower Cretaceous with an important lacuna of deposition from the Aptian to the Turonian that has only been observed in the western Kopet Dagh. Large out-of-sequence thrusts that affect the whole stratigraphic sequence are observed (Figure 14). They are obliquely cutting the previous structures such as the Kashafrud rift, which suggests that they are newly-formed and do not correspond to inversion of the rift faults. Limestones of the Tirgan Formation are folded and faulted with a short wavelength which suggests the occurrence of local decollement levels within the underlying Chaman Bid Formation. The series is continuing towards the West (Figure 14) with the occurrence of folds with Kashafrud and Mozduran formations in the core that are cross-cut by the newly-formed South-verging thrusts. To the North, within the northern flank of the Bash Kalateh anticline, the Lower Cretaceous series (1300 m thick) are outcropping, whereas they were absent in the Nabiya syncline. They consist of calcareous with clastic components of the Zard Formation and expand up to the Aitamir Formation characterized by its limonitic shales.

Conglomerates ( $\sim 40 \mathrm{~m}$ thick) are characterized an erosion level on the top of the Aitamir Formation and they are overlain by the white limestones of the Abderaz Formation that are the only sediments from the Upper Cretaceous. The marine marls of the Eocene directly overlie the Upper Cretaceous. The entire series is concordant and presents a constant dipping whereas the Oligocene-Neogene conglomerate is subhorizontal. Toward the NW, a nar- 
row South-verging anticline with a core made of Upper Jurassic Mozduran Formation is thrusted to the South by the Takal Kuh Fault. The Lower Cretaceous series thickens and is unconformably overlain by sediments from the Upper Cretaceous Kalat Formation to the Eocene Khangiran Formation. NW verging large anticlines and synclines are observed, as well as an important thickening of the Lower Cretaceous series that is related to a higher initial thickness and to the occurrence of thrusting within this formation. In contrast, there is a lack of most of the Upper Cretaceous in the last syncline (Rud Atkak syncline) that has a core made of Paleocene sediments. At the western end of the section, some seismic lines illustrate that the folds of the Kopet Dagh are plunging laterally below the Gorgan plain sediments (Figure refloca). Along the section, an important angular unconformity between the folded Aitamir Formation and the Oligocene-Neogene conglomerates is observed. We have already observed the folded Eocene sediments that have been eroded before the deposition of a sub-horizontal Oligocene-Neogene conglomerate. The seismic sections show buried anticlines and the post-Eocene unconformity, which is affected by some recent thrust faults. A drill was done in this region, but due to numerous thrusts and repetitions, it did not reach the Lower Cretaceous Tirgan carbonates.

\subsubsection{Summary of the western Kopet Dagh cross-section}

This cross-section is characterized by important lateral variations of the formations thicknesses as a consequence of either several unconformity or lateral sediment thickness variations inherited from the deposition of the series. There is a lacuna in the Lower Cretaceous to the East and in the Upper Cretaceous to the West. There are also facies variations and thick- 
ening of the Lower Cretaceous toward the West. The unconformity at the base of the Lower Cretaceous (Kalat Formation) is truncated by the postEocene unconformity. These several erosional surfaces are associated with stratigraphic lacunas are observed from the Lower Cretaceous to the Eocene, but they are not associated with angular unconformities, in contrast tothe major angular unconformity characterizing the base of the post-Eocene series. The entire series until the Late Eocene is folded within double-verging structures. Newly-formed thrusts cross-cut the previous structures of the Kashafrud graben.

4.4. Gorgan Plain cross-section: from the Eastern Caspian Sea margin to the Gorgan Plain

This part presents the westernmost Kopet Dagh cross-section that is linked with the eastern part of the South Caspian Sea Basin above the Gorgan Plain (Figure 15). The Gorgan Plain is the southern prolongation of a larger delta that outcrops in Turkmenistan, along the CaspianSea. Numerous wells and discoveries were made in this region where the fields present an arcuate shape along the coast (Figure 1b) and produce into the Lower and Middle Pliocene clastic series. In this region, the folds are oriented SWSENE, but they are masked by the Quaternary sediments that outcrop in the Gorgan Plain in Iran. Discovery of gas and condensates was made in one of this buried folded structure, within the Lower Cretaceous carbonates of the Tirgan Formation. 


\subsubsection{Description of the Gorgan Plain cross-section}

According to borehole data and similarly to the western Kopet Dagh cross-section, the Gorgan Plain cross-section shows an important angular unconformity between folded and trangressive series that are consequent to the important Tertiary subsidence in the South Caspian Sea Basin. The folds affecting the Upper Cretaceous series present an asymmetry towards the NW and they prolong the folded structures belonging to the Kopet Dagh range (Figure 15) as attested by borehole data and seismic sections (Figures 16 and $17)$.

Above the unconformity, progressive onlap of the series characterizes the border of the South Caspian Sea Basin. However, these series as well as the unconformity are locally slightly folded as a consequence of the late Alpine phase.

Figure 17 presents a composite seismic section close to the Caspian Sea coast and shows the prolongation of the folded structures underneath the unconformity, which is affected by local reactivation. Above the unconformity, the clastic series thickens greatly towards the South Caspian Sea as a consequence of several transgressive episodes. Regional correlations enable to propose that the yellow horizon nearly corresponds to the top-Miocene.Between the yellow horizon and the unconformity, normal faults sitted on top of a disharmony are observed, highlighting a shale ridge structure (indicated with the (M?) on the Figure 17). The clay series of the Oligocene Maykop Formation of the South Caspian Sea Basin are often responsible of the development of shale ridges type structures, which suggests an Oligocene age for the series sitting on top of the unconformity. 


\subsubsection{Summary of the Gorgan Plain cross-section}

This cross-section shows the relationship between the Kopet Dagh anity folds uplifted and eroded after the Eocene marine transgression. The trend of the buried folds is SSW-NNW, which is parallel to the structures of the western part of the Kopet Dagh range. The processes involved for the onset of the rapid Oligocene until recent times subsidence is still debated but several authors proposed a syn-compressional downward buckling of the basin resistant basement (Korotaev et al., 1999) and/or the onset of the subduction below the Apsheron ridge (Allen et al., 2003). Progressive onlap above the unconformity in the Gorgan Plain are observed within the Oligo-Miocene clastic sediments. The trend of the Maykop ridge along the coast of the Turkmenistan suggests an Oligo-Miocene paleodelta of the Amu Darya river in that region. This proto-delta shifts to the $\mathrm{N}$ during the Pliocene, possibly as a consequence to the rapid uplift within the Kopet Dagh and Alborz ranges at that time.

\section{Discussions on the geodynamic evolution}

Based on our new stratigraphic and structural data correlated with already published data, we decipher the geodynamic evolution of the Kopet Dagh range and its relationships with the adjacent Amu Darya and South Caspian Sea basins (Figures 18 and 19).

\subsection{Late Triassic to Early Jurassic}

The collision between Central Iran and Turan plates (Cimmerian orogeny) follows the northward subduction of the Paleotethys Ocean and occurred 
during the latest Triassic/Early Jurassic (Zanchetta et al., 2013) (Figure 18a). The trend of the main structures of the northwestern and eastern parts of the Kopet Dagh follows the arcuate shape of the Paleotethys suture zone, which emphasizes the importance of the structural inheritance in the presentday structure of the belt. Furthermore, some authors suggest an important oblique component of the convergence from a detailed structural study on transpressional structures within the Aghdarband window (Zanchi et al., 2010). They infer the reactivation of some Paleozoic structures as major strike-slip faults during the Cimmerian orogeny. Those linear structures are observed North of the Amu Darya Basin (Mangyshlak and Ustyurt ridges) and within the Kopet Dagh (Main Kopet Dagh Fault) and they have been recently reactivated too (Ulmishek, 2001). From a petroleum point of view, the coal beds of the Upper Triassic sequence (Miankuhi Formation) could be a potential source rock but this formation was deposited within the narrow Aghdarband back-arc basin (Zanchetta et al., 2013) and it is hard to infer its present extension.

\subsection{Middle Jurassic}

After the Cimmerian collision (Figure 18b), a post-orogenic rifting phase took place across the studied area with the deposition of the clastic Middle Jurassic Kashafrud Formation. Seismic sections show that the Middle Jurassic Kashafrud Formation was deposited in a rift system, as suggested by the lack or near lack of this formation above pre-Jurassic basement highs in opposition within the hanging wall of the normal faults where this formation reaches several thousand meters thick. Furthermore, evidences of preserved Middle Jurassic normal faulting have been observed at several places in the 
field. The top of the Middle Jurassic Kashafrud Formation is marked by an important erosional surface and locally by an angular unconformity with the overlying series.

This Middle Jurassic rift system in the Kopet Dagh region has been coeval with the South Caspian Sea rifting event (Brunet et al., 2003). From a petroleum point of view, the Kashafrud Formation is considered as one of the main source rocks of the Amu Darya Basin, but forms a bad reservoir, because of early diagenesis (Poursoltani and Gibling, 2011).

\subsection{Late Jurassic / Early Cretaceous}

The Upper-Jurassic to Early Cretaceous series observed in the Kopet Dagh range also belong to the southern part of the Amu Darya Basin (Figure 18c). We infer the occurrence of gentle paleohighs in the eastern part of the Kopet Dagh to explain variations in facies and thickness of the series from the Upper Jurassic to the Lower Cretaceous. For example, to the North of the Aghdarband erosional windows, Upper Jurassic Mozduran limestone is reduced to few meters and there are no salt or evaporites above, in contrast to the observations made in the Amu Darya Basin.

From a petroleum point of view, the carbonates of the Mozduran Formation as well as the clastics of the Shurijeh Formation are the main reservoirs of the Amu Darya Basin. Towards the South, in the Kopet Dagh, there is no salt on top of the Jurassic calcareous and the Upper Jurassic to Lower Cretaceous series are thinner and more clastic. 


\subsection{Late Cretaceous / Eocene}

In the northern and western parts of the Kopet Dagh range, several local erosional levels are observed (Figure 3). For example, a large hiatus from the late Barremian to the Santonian, as well as important thickness and facies variations are observed on the western cross-section (Figure 13). Furthermore, the uppermost Cretaceous (Maastrichtian) is a stratigraphic hiatus, which is generalized in the whole Kopet Dagh region. Our results suggest several local tectonic uplifts in the southern part of the Amu Darya Basin during the Late Cretaceous (Figure 18d). The Paleocene series present important facies variations from red continental series to carbonates across the belt whereas the Eocene Khangiran Formation marks the last marine episode recorded in the Amu Darya Basin and it does not present important thickness or facies variations.

Some authors report evidences for a Late Cretaceous-Paleocene compression event in northern Iran (Barrier and Vrielynck, 2008) but this event is not well described at the moment. Notwithstanding, exhumation of the blue schist facies rocks within the Zagros belt and the exhumation of high-pressure rocks in the Sistan are broadly coincident with the obduction process of the Neotethyan lithosphere onto Arabia (Agard et al., 2011). Agard et al. (2011) propose that these exhumation phases could be the result of a regional-scale modification of plate-slab coupling in the Neotethys subduction zone during Late Cretaceous time. Further investigations in northern Iran are needed to better describe these compressive events. 


\subsection{Late Eocene / Early Oligocene: onset of the Alpine orogeny}

The thick-skin uplift and folding of the Kopet Dagh during the Alpine orogeny may be related to reactivation of former Paleozoic or Cimmerian fault systems (Figure 19a). This is suggested by the linear front of the Eastern and Central Kopet Dagh structures, which diverges in the western Kopet Dagh where they are influenced by the presence of the Paleotethys suture zone and of the South Caspian rigid block to the NW. This thickskin deformation could be associated with a crustal thickening phase that is observed from geophysical modeling (Jiménez-Munt et al., 2012; Robert et al., in prep). During the main Alpine compressive phase, folding style and structures vary laterally as a function of pre-existing structures, rock behavior and mechanical stratigraphy (Figure 19a). In the southeastern part of the Kopet Dagh, the Paleotethys suture zone and the inherited Paleozoic trend of the Main Kopet Dagh Fault are parallel. These pre-existing structures probably control both the location of the Alpine Kopet Dagh uplift and folding and the basement-involved tectonic style we observed. Some local inversions of Middle Jurassic graben were also highlighted even though evidences of force folding within the Upper Jurassic to Lower Cretaceous (Barremian) series have been shown too. On top of the Barremian series, several dcollements located within the thick Aptian-Albian marls lead to the formation of the triangle zone. Quite similar structures have already been described in Venezuela Andes (Colletta et al., 1997; Duerto et al., 2006, e.g.) or in the frontal part of Longmen Shan range (Robert et al., 2010, e.g.). Towards the West, the structures are dominated by the resistance contrast between the rigid block formed by the basement of the South Caspian Sea 
Basin and the weaker western part of the Kopet Dagh range that has been previously deformed by the Cimmerian orogeny. Indeed, this deformation contrast results in the indentation of the rigid South Caspian Sea region during the Alpine compression (Allen et al., 2003). The deformation style is characterized by the double vergence of deep-seated thrusts faults (Figure 8) and important disharmonies within the Mesozoic levels. Fish-tail type structures with dcollement levels within Jurassic or Cretaceous shale levels are suggested. In this part, there is not much evidence of reactivation of the normal faults associated to the Middle Jurassic rifting faults and numerous short-cuts have been observed.

Marine sediments up to the Late Eocene are folded with the underlying formation during the Alpine phase. Eocene sediments are clipped inside the synclines and are unconformably covered by post-Eocene series. Within the Kopet Dagh range, most of the Oligocene-Neogene series are discordant, but growth strata within the Oligocene-Neogene series were observed in the southeastern part of the belt. Further datings of these series are needed, but a Late Eocene-Early Oligocene age for onset of the Alpine orogeny within the Kopet Dagh belt can be proposed.

\subsection{Oligocene to Mid-Pliocene: Important subsidence in the South Caspian} Sea Basin

The rapid subsidence of the South Caspian Sea starts just after the Late Eocene-Early Oligocene compression folding that is responsible for the main uplift phase within the Kopet Dagh and the Alborz mountains (Allen et al., 2003; Brunet et al., 2003). Most of the authors agree that the basement of the South Caspian Sea is an oceanic crust resulting from the opening of a 
back-arc basin north of the Neotethyan arc (Brunet et al., 2003). According to Allen et al. (2003), the South Caspian Sea basement corresponds to a resistant block with almost no internal deformation, playing an indentor role, which could explain the arcuate shape of the surrounding fold-and-thrusts belts (Alborz, Kopet Dagh, and Talysh). The important thickness of the Caspian series is sealing the previously described structures in the western Kopet Dagh. Progressive onlap of these Oligocene and Miocene series on top of the unconformity is observed on seismic sections. The structures with hydrocarbon discoveries that exist along the western coast of Turkmenistan up to the Moghan Plain in Iran (Figure 1b) are associated with the deep shale ridges of the Oligocene Maykop Formation. These arch structures correspond to a Miocene proto Amu Darya delta in that region and the development of shale ridge in the delta front during the Miocene. An increase of the subsidence rate was observed during the latest Miocene and Pliocene periods and the Amu Darya River shifted to a northward position. This new large prograding system towards the South Caspian Sea Basin is associated with the deposition of the Lower Pliocene main reservoirs. It cover nearly half of the surface of the South Caspian Sea Basin with the development of a new delta front oriented NE-SW in the central part of the basin.

\subsection{Mid-Pliocene to Present day: Indentation and onset of the extrusion in} the Kopet Dagh

Major changes of tectonic regime have been highlighted during the PlioQuaternary at the scale of the South Caspian Sea Basin and its surrounding domains (Axen et al., 2001; Allen et al., 2004; Copley and Jackson, 2006; Abbassi et al., 2009; Shabanian et al., 2009a) (Figure 19c). Moreover, con- 
version from mainly thrusting to oblique-slip and strike-slip faulting within the Kopet Dagh range occurred during the late Cenozoic ( $\sim 4-5 \mathrm{Ma})$ as a consequence of the major tectonic reorganization in NE Iran (Shabanian et al., 2009a,b). Ritz et al. (2006) suggested that a northwestward motion of the South Caspian Sea Basin compared to Eurasia and/or its clockwise rotation could explain this tectonic reorganization. Masson et al. (2006) proposed a second tectonic force due to the initiation of the northward subduction of the oceanic basement of the South Caspian Sea Basin below the Apsheron ridge.

In the Gorgan Plain and along the Turkmen margin of the Caspian Sea, the discordant series lying on top of the older series folded by the first Alpine phase are deformed too (Figure 15). This deformation implies a refolding of the unconformity by reactivation of the underlying structures. Oblique inversion of the Kashafrud grabens and strike-slip along the Main Kopet Dagh Fault, which extends from the South Caspian Sea to the Afghan border are associated with this late deformation phase. En echelon pattern of the folds along this zone and en echelon fault pattern observed on 3D seismic blocks demonstrate a dextral shear component during the folding and inversion/reactivation. The importance of the strike-slip faults is demonstrated by the present-day seismicity across the range as well as by geomorphological data.

\section{Conclusions}

In this paper, we provide a detailed and revised characterization of the stratigraphy and the tectonics of the Kopet Dagh belt from new stratigraphic, 
structural and seismic data. Based on these new data, we are able to define the tectonic history of the Kopet Dagh, which is most likely related with the adjacent South Caspian Sea and Amu Darya basins. We focused our study on the deformation recorded within the Kopet Dagh after the Cimmerian orogeny, which corresponds to the closure of the Paleotethys Ocean. The main unconformity that is widely described within the Kopet Dagh, is located at the base of the first deposited sediments after the Cimmerian orogeny: the Middle Jurassic Kashafrud Formation. We highlighted abrupt facies and thickness changes within the Middle Jurassic Kashafrud Formation, as well as evidences of active rifting during the deposition of this formation from seismic sections. The onset of deposition of the Amu Darya Basin corresponds to the Middle Jurassic synchronously to the initiation of active rifting.

Within the thick sedimentary sequence, we evidence several hiatus during the Cretaceous and the Paleocene in the northwestern part of the belt. These sedimentary hiatus highlight several local uplifts, suggesting a tectonic reactivation of the belt as early as during the Late Cretaceous/Paleocene. These local uplifts can be interpreted as the consequence of the distal closure of small oceanic domains, such as the Sistan Ocean. Finally, the onset of the Alpine compression occurred after the deposition of the marly Khangiran Formation during the Eocene and resulted in the inversion of segments of the Jurassic-Cretaceous sedimentary basin and the reactivation of their bounding faults as well as newly created thrusts. Towards the South Caspian Sea Basin, we highlighted a major Late Eocene unconformity with progressive onlap above this unconformity, which indicates an age for the tectonic re- 
activation of the belt as early as Late Eocene-Early Oligocene. In contrast, there is no precise timing for the activation of the Alpine tectonics in the eastern part of the belt. In the western part of the belt, the double-verging structures consist of thrust faults involving basement and fault-propagation folds within the sedimentary sequence. The entire succession until the Late Eocene is folded and newly-formed thrusts cross-cut the previous structures of the Middle Jurassic Kashafrud grabens. In the eastern part of the belt, this study demonstrates Middle Jurassic graben inversion with evidences of forced-folding and few short-cuts, as well by larger structures involving basement. Furthermore, seismic sections evidence several décollement levels within the Mesozoic sequence, which explains numerous disharmonies and fish-tails structures.

The important subsidence in the South Caspian Sea Basin began during the Early Oligocene and it is responsible for the sealing of the structures by the thick Oligocene to Quaternary sedimentary sequences in the western part of the belt. Finally, the tectonic reorganization in North Iran since the Pliocene is responsible for the dominance of the strike-slip component in the present-day deformation affecting the Kopet Dagh.

\section{Acknowledgments}

This study was funded by the Darius Consort2009bum and thanks to the strong support and collaboration with the National Iranian Oil Company (NIOC). Additional funding was provided by the projects ATIZA(CGL200909662-BTE) and TECLA (CGL201126670). The authors are very grateful to geologists from the NIOC for their support during the field missions and 
for the help they provided in publishing this study.

\section{References}

Abbassi, A., Nasrabadi, A., Tatar, M., Yaminifard, F., Abbassi, M. R., Hatzfeld, D., Priestley, K., 2009. Crustal velocity structure in the southern edge of the Central Alborz (Iran). Journal of Geodynamics 49, 68-78.

Afshar-Harb, A., 1979. The stratigraphy, tectonics and petroleum geology of the Kopet Dagh Region, northern Iran. Ph.D. thesis, Imperial College of Science and Technology, University of London.

Agard, P., Omrani, J., Jolivet, L., Whitechurch, H., Vrielynck, B., Spakman, W., Monié, P., Meyer, B., Wortel, R., 2011. Zagros orogeny: a subductiondominated process. Geol. Mag. 148 (5-6), 692-725.

Aghanabati, A., 2004. Geology of Iran. Geological survey of Iran publication, $558 \mathrm{p}$.

Alavi, M., 1992. Thrust tectonics of Binalood region, NE Iran. Tectonics 11, $360-370$.

Alavi, M., Vaziri, H., Emami, K. S., Lasemi, Y., 1997. The triassic and associated rocks of the Agh-Darband areas in central and northeastern Iran as remnant of the southern Turanian active continental margin. GSA Bulletin 109, 1563-1575.

Allameh, M., Torshizian, H., Moradian, F., Amandar, B., 2010. Study of ostracodes in Abderaz Formation in Kopet-Dagh Basin, the 1st Interna- 
tional Applied Geological Congress, Department of Geology, Islamic Azad University - Mashad Branch, Iran.

Allen, M., Jackson, J., Walker, R., 2004. Late Cenozoic reorganization of the Arabia-Eurasia collision and the comparison of short-term and long-term deformation rates. Tectonics 23 .

Allen, M. B., Vincent, S. J., Alsop, G. I., Ismalail-zadeh, A., Flecker, R., 2003. Late Cenozoic deformation in the South Caspian region: effects of a rigid basement block within a collision zone. Tectonophysics 366, 223-239.

Amurskiy, G. I., 1971. The deep structure of the Kopetdagh. Geotectonics $1,34-40$.

Axen, G. J., Lam, P. S., Grove, M., Stockli, D. F., Hassanzadeh, J., 2001. Exhumation of the west-central Alborz Mountains, Iran, Caspian subsidence, and collision-related tectonics. Geology 29 (6), 559-562.

Barrier, E., Vrielynck, B., 2008. Palaeotectonic maps of the Middle East. MEBE Programme. Atlas of 14 maps, CCGM.

Baud, A., Stampfli, G., 1989. Tectonogenesis and evolution of a segment of the Cimmerids: The volcano-sedimentary Triassic of Agh-Darband (Kopet Dagh, North-East Iran). In: SENGOR, A.M.D., (Ed.): Tectonic evolution of the Tethyan Region, Kluwer, Dordrec, 265-275.

Berberian, M., 1983. The Southern Caspian: A compressional depression floored by a trapped, modified oceanic crust. Canadian Journal of Earth Sciences 20 (2), 163-183. 
Berberian, M., King, G. C. P., 1981. Towards a paleogeography and tectonic evolution of iran. Canadian Journal of Earth Sciences 18, 1764-1766.

Brunet, M.-F., Korotaev, M. V., Ershov, A. V., Nikishin, A. M., 2003. The South Caspian Basin : a review of its evolution from subsidence modelling. Sedimentary Geology 156, 119-148.

Colletta, B., Roure, F., de Toni, B., Loureiro, D., 1997. Tectonic inheritance, crustal architecture, and contrasting structural styles in the Venezuela Andes. Tectonics.

Copley, A., Jackson, J., 2006. Active tectonics of the Turkish-Iiranian plateau. Tectonics 25 (TC6006).

Dikenshteyn, G., Maksimov, S., Semenovich, V., 1983. Petroleum provinces of the URSS (Neftegazonosynye provintsii SSSR), moscow, Nedra, 272p.

Duerto, L., Escalona, A., Mann, P., 2006. Deep structure of the Meacuterida Andes and Sierra de Perijaacute mountain fronts, Maracaibo Basin, Venezuela. AAPG Bulletin 90 (4), 505-528.

Emami, K. S., Fürsich, F. T., Wilmsen, M., 2004. Documentation and significance of tectonic events in the northern Tabas block (East-central Iran) during the Middle and Late Jurassic. Revista Italica di Paleontologia Stratigrafia 110 (1), 163-171.

Garzanti, E., Gaetani, M., 2002. Unroofing history of late Paleozoic magmatic arcs within the Turan Plate (Tuarkyr, Turkmenis tani). Sedimentary Geology 151, 67-87. 
Golonka, J., 2004. Plate tectonic evolution of the southern margin of Eurasia in the Mesozoic and Cenozoic. Tectonophysics 381, 235-273.

Hollingsworth, J., Fattahi, M., Walker, R., Talebian, M., Bahroudi, A., Jackson, M. J., Copley, A., 2010. Oroclinal bending, distributed thrust and strike-slip faulting, and the accommodation of Arabia-Eurasia convergence in NE iran since the Oligocene. Geophysical Journal International $181,1214-1246$.

Hollingsworth, J., Jackson, J., Walker, R., Gheitanchi, M., Bolourchi, M., 2006. Strike-slip faulting, rotation, and along-strike elongation in the Kopeh dagh mountains, ne iran. Geophys. J. Int. 166, 1161-1177.

Hollingsworth, J., Jackson, J., Walker, R., Nazari, H., 2008. Extrusion tectonics and subduction in the eastern South Caspian region since 10 Ma. Geology 36 (10), 763-766.

Hollingworth, J., 2007. Active tectonics of ne iran. Ph.D. thesis, Queen's college, University of Cambridge.

Jamali, F., Hessami, K., Ghorashi, M., 2011. Active tectonics and strain partitioning along dextral fault system in Central Iran: analysis of geomorphological observations and geophysical data in the Kashan region. Journal of Asian Earth Sciences 40, 1015-1025.

Jiménez-Munt, I., Fernàndez, M., Saura, E., Vergés, J., Garcia-Castellanos, D., 2012. 3D lithospheric structure and regional/residual Bouguer anomalies from Arabia-Eurasia collision in Iran. Geophys. J. Int. xxx. 
Kalantari, A., 1969. Foraminifera from the Middle Jurassic-Cretaceous succession of Kopet-dagh region. NIOC, Geological Laboratory Publication.

Kavoosi, M., Lasemi, Y., Sherkati, S., Moussavi-Harami, R., 2009a. Facies analysis and depositional sequences of the Upper Jurassic Mozduran Formation, a reservoir in the Kopet Dagh Basin, NE iran. Journal of Petroleum Geology 32 (3), 235-260.

Kavoosi, M., Sepehr, M., Sherkati, S., 2009b. The kopet-dagh basin evolution during middle-late jurassic. Extended abstracts EAGE Meeting, Shiraz, Iran.

Korotaev, M., Ershov, A., Nikishin, A., Brunet, M. F., 1999. Sedimentary basins in compressional environment-modelling of the rapid subsidence. EAGE Meeting, June, 1999, Helsinki, Finland. Extended abstract.

Lyberis, N., Manby, G., 1999. Oblique to orthogonal convergence across the Turan Block in the post-Miocene. AAPG Bulletin 83 (7), 1135-1160.

Lyberis, N., Manby, G., Poli, J.-T., Kalougin, V., Yousouphocaev, H., Ashirov, T., 1998. Post-triassic evolution of the southern margin of the Turan plate. C.R. Acad. Sci. Paris 326, 137-143.

Maggi, M., Jackson, J., McKenzie, D., Priestley, K., 2000. Earthquake focal depths, effective elastic thickness, and the strength of the continental lithosphere. Geology 28 (6), 495-498.

Majadifard, M., 2003. Biostratigraphy, lithostratigraphy, ammonite taxonomy and microfacies analysis of the Middle and Upper Jurassic of north- 
eastern Iran. Ph.D. thesis, Der Bayerischen Julius-Maximilians-Universität Würzburg.

Martini, E., 1971. Standard Tertiary and Quaternary calcar- eous nannoplankton zonation. In: Second Planktonic Conference. Rome, pp. 739-785.

Masson, F., Djamour, Y., Gorp, S. V., Chéry, J., Tatar, M., Tavakoli, F., Nankali, H., Vernant, P., 2006. Extension in NW Iran driven by the motion of the South Caspian Basin. Earth and Planetary Science Letters 252, 180188.

Moussavi-Harami, R., Brenner, R., 1990. Lower Cretaceous (Neocomian) fluvial deposits in eastern Kopet-Dagh Basin, northeastern Iran. Cretaceous Research 11, 163-174.

Moussavi-Harami, R., Brenner, R., 1992. Geohistory analysis and petroleum reservoir characteristics of Lower Cretaceous (Neocomian) sandstones, eastern Kopet Dagh Basin, northeastern Iran. American Association of Petroleum Geologists Bulletin 76, 1200-1208.

Moussavi-Harami, R., Mahboubi, A., Nadjafi, M., Brenner, R. L., Mortazavi, M., 2009. Mechanism of calcrete formation in the Lower Cretaceous (Neocomian) fluvial deposits, northeastern Iran based on petrographic, geochemical data. Cretaceous Research 30, 1146-1156.

Muttoni, G., Mattei, M., Balini, M., Zanchi, A., Gaetani, A., Berra, F., 2009. The drift history of Iran from the Ordovician to the Triassic. Geological Society of London, Special Publication: South Caspian to Central Iran Basins 312, 7-29. 
Perch-Nielsen, K., 1985. Mesozoic calcareous nannofossils, in Bolli, H.M., Saunders, J.B., and Perch-Nielsen. Plankton Stratigraphy: Cambridge, Cambridge University Press, 330-426.

Poursoltani, M. R., Gibling, M. R., 2011. Composition, porosity, and reservoir potential of the Middle Jurassic Kashafrud Formation, northeast Iran. Marine and Petroleum Geology 28 (5), 1094 - 1110.

Poursoltani, M. R., Moussavi-Harami, S. R., Gibling, M. R., 2007. Jurassic deep-water fans in the Neo-Tethys Ocean: The Kashafrud Formation of the Kopet-Dagh basin, Iran. Sedimentary Geology 198 (1), 53-74.

Raisossadat, S. N., Shokri, M. H., 2011. Biostratigraphic studies of the Lower Cretaceous (Upper Barremian-Lower Aptian) Sarcheshmeh and Sanganeh formations in the Kopet Dagh basin, NE Iran: An integration of calcareous nannofossil and ammonite stratigraphies. Stratigraphy and Geological Correlation 19 (2), 188-204.

Reilinger, R., McClusky, S., Vernant, P., Lawrence, S., Ergintav, S., Cakmak, R., Ozener, H., Kadirov, F., Guliev, I., Stepanyan, R., Nadariya, M., Hahubia, G., Mahmoud, S., Sakr, K., ArRajehi, A., Paradissis, D., Al-Aydrus, A., Prilepin, M., Guseva, T., Evren, E., Dmitrotsa, A., Filikov, S., Gomez, F., Al-Ghazzi, R., Karam, G., 2006. GPS constraints on continental deformation in the Africa-Arabia-Eurasia continental collision zone and implications for the dynamics of plate interactions. Journal of Geophysical Research B: Solid Earth 111 (5).

Ritz, J.-F., Nazari, H., Ghassemi, A., Salamati, R., Shafei, A., Solaymani, 
S., Vernant, P., 2006. Active transtension inside central Alborz: a new insight into northern Iran-southern Caspian geodynamics. Geology 34 (6), $477-480$.

Robert, A., Jiménez-Munt, I., Fernàndez, M., Vergés, J., in prep. Lithospheric structures in Central Eurasia derived from elevation, geoid anomaly and a thermal analysis. Geochemistry, Geophysics, Geosystems.

Robert, A., Pubellier, M., de Sigoyer, J., Vergne, J., Lahfid, A., Cattin, R., Findling, N., Zhu, J., 2010. Structural and thermal characters of the Longmen Shan (Sichuan, China). Tectonophysics 491 (1-4), 165-173.

Ruttner, A., 1991. The Triassic of Aghdarband (AgDarband), NE-Iran, and its pre-Triassic frame. Abhandlungen der Geologischen Bundesanstalt 38, $252 \mathrm{p}$.

Sengor, A. M. C., 1990. A new model for the late Palaeozoic-Mesozoic tectonic evolution of Iran and implications for Oman. Geological Society of London, Special Publications 49, 797-831.

Shabanian, E., Bellier, O., Siame, L., Abbassi, M. R., Bourlès, D., Braucher, R., Farbod, Y., 2012. The Binalud Mountains: A key piece for the geodynamic puzzle of NE iran. Tectonics 31 (TC6003).

Shabanian, E., Bellier, O., Siame, L., Arnaud, N., Abbassi, M. R., Cochemé, J.-J., 2009a. New tectonic configuration in NE Iran: Active strike-slip faulting between the Kopet Dagh and Binalud mountains. Tectonics 28 (TC5002). 
Shabanian, E., Siame, L., Bellier, O., Benedetti, L., Abbassi, M. R., 2009b. Quaternary slip rates along the northeastern boundary of the ArabiaEurasia collision zone (Kopeh Dagh Mountains, Northeast Iran). Geophysical Journal International 178, 1055-1077.

Shahidi, A., 2008. Evolution tectonique du Nord de l'Iran (Alborz et Kopet Dagh) depuis le Mésozoïque. Ph.D. thesis, Université Pierre et Marie Curie - Paris VI.

Sharafi, m., ashuri, m., Mahboubi, A., Moussavi Harami, S. R., December 2012. Stratigraphic application of Thalassinoides ichnofabric in delineating sequence stratigraphic surfaces (Mid-Cretaceous), Kopet-Dagh Basin, northeastern Iran. Palaeoworld 21 (3), 202-216.

Sheikholeslami, M., Kouhpeym, M., 2012. Structurale analysis and tectonic evolution of the eastern Binalud Mountains, NE Iran. Journal of Geodynamics $61,23-46$.

Taheri, J., Fürsich, F., Wilmsen, M., 2009. Stratigraphy, depositional environments and geodynamic significance of the Upper Bajocian Bathonian Kashafrud Formation, NE Iran. Geological Society of London, Special Publication, South Caspian to Central Iran Basins 312, 205-218.

Tavakoli, F., 2007. Present-day deformation and kinematics of the active faults observed by GPS in the Zagros and East of Iran. Ph.D. thesis, Université Joseph Fourier - Grenoble I.

Thierstein, H. R., 1976. Mesozoic calcareous nannoplankton biostratigraphy of marine sediments. Marine Micropaleontology 1, 325-362. 
Thomas, J., Cobbold, P., Shein, V., Douaran, S. L., 1999. Sedimentary record of Late Paleozoic to recent tectonism in Central Asia-analysis of subsurface data from the Turan and South Kazakh domains. Tectonophysics 313, 243263.

Ulmishek, G. F., 2001. Petroleum geology and resources of the Middle Caspian basin, former Soviet Union. U.S. Geological Survey Bulletin 99, $116 \mathrm{p}$.

Ulmishek, G. F., 2004. Petroleum geology and resources of the Amu-Darya Basin, Turkmenistan, Uzbekistan, Afghanistan, and Iran. U.S. Geological Survey Bulletin 2201-4, 32p.

Vernant, P., Nilforoushan, F., Hatzfeld, D., Abbassi, M. R., Vigny, C., Masson, F., Nankali, H., Martinod, J., Ashtiani, A., Bayer, R., Tavakoli, F., Chery, J., 2004. Present-day crustal deformation and plate kinematics in the Middle East constrained by GPS measurements in Iran and northern Oman. Geophys. J. Int 157, 381-398.

Wilmsen, M., Fürsich, T., Emami, K. S., Majidifard, M. R., Taheri, M. R., 2009. The Cimmerian Orogeny in northern Iran: tectono-stratigraphic evidence from the foreland. Terra Nova 21, 221-218.

Zanchetta, S., Berra, F., Zanchi, A., Bergomi, M., Caridroit, M., Nicorab, A., Heidarzadeh, G., 2013. The record of the Late Palaeozoic active margin of the Palaeotethys in NE Iran: Constraints on the Cimmerian orogeny. Gondwana Research 24 (3-4), 1237-1266. 
Zanchi, A., Balini, M., Ghassemi, M. R., Zanchetta, S., 2-7 May 2010. Mechanism of calcrete formation in the Lower Cretaceous (Neocomian) fluvial deposits, northeastern Iran based on petrographic, geochemical data, EGU General Assembly.

Zanchi, A., Berra, A., Mattei, M., Ghasemi, M. R., Sabouri, J., 2006. Inversion tectonics in Central Alborz, Iran. Journal of Structural Geology 28, 2023-2037.

Zanchi, A., Zanchetta, S., Berra, F., Mattei, M., Garzanti, E., Molyneux, S., Nawab, A., Sabouri, J., 2009. The Eo-Cimmerian (Late? Triassic) orogeny in North Iran. Geological Society of London, Special Publications $312,31-55$.

Figure 1: a. Topographic map (ETOPO 1 data) of Iran showing the main tectonic units with location of the main volcanic rocks, salt and ophiolites outcrops. Neotethys and Paleotethys sutures zones are indicated. MKF: Main Kopet Dagh Fault; GKF: Great Kavir Fault; GKB: Great Kavir Basin; ABS: Apsheron-Balkhan System b. Topographic map of the Kopet Dagh range from ASTER GDEM data showing the location of the gas and oil fields (red area) from publications (Dikenshteyn et al., 1983; Ulmishek, 2004) and from the Oil and Gas Infrastructure in the Caspian Sea region, March 2001 from the United State Government. The Paleotethys suture zone and major places are indicated on this map. Major gas fields: 1: Dauletabad; 2: Gonbadli; 3: Khangiran; 4: Shaltyk; 5: Bayram-Ali; 6: Achak 
Figure 2: Seismotectonic map of the Kopet Dagh region where the major recent faults are represented according to (Hollingsworth et al., 2006; Hollingworth, 2007; Hollingsworth et al., 2008, 2010; Shabanian et al., 2009a,b, 2012). Blue arrows represent GPS velocities relative to Eurasia fixed; the error ellipses indicate formal errors within 95 percent confidence interval (Tavakoli, 2007). The location of the Paleotethys suture zone is indicated. Focal mechanisms are taken from CMT Harvard catalogue for the period 1976-2012. The shaded relief background has been made from ASTER GDEM data. DF: Doruneh Fault; KF: Khazar Fault; MKF: Main Kopet Dagh Fault; NFS: Neyshabur Fault System.

Figure 3: New stratigraphic chart of the Kopet Dagh belt and of two main adjacent Amu Darya and South Caspian Sea basins. This stratigraphic study has been constructed from our 159 biostratigraphic datings, sedimentologic observations and a wide compilation of published data. Major tectonic events are been indicated on this stratigraphic chart and can be correlated with the main regional observed hiatus.

Figure 4: a) Prograding sequence of limestones belonging to the Upper Jurassic Mozduran Formation within the upper part of the upper Jurassic shally Chaman Bid Formation b) Clastic filling between 2 reefs within the Upper Jurassic Mozduran Formation. Similar features have been observed on seismic sections as highlighted in Figure 10.

Figure 5: Simplified geological map of the Kopet Dagh area compiled from the geological maps of the Geological Survey of Iran. Locations of the 4 regional cross-sections presented in this article are indicated. 
Figure 6: The Aghdarband-Gonbadly cross-section (see location of the cross-section in Figure 5. This cross-section shows structural relationships between the rocks deformed by the Hercynian and/or the Cimmerian orogeny that outcrop in the Aghdarband erosional windows and the series deposited in the southwestern part of the Amu Darya Basin affected by the Alpine inversion of the Middle Jurassic extensional structures. Locations of the seismic data presented in this article and borehole data are indicated.

Figure 7: Tectonic sketch of the Aghdarband erosional window, modified from previous published cross-sections (Ruttner, 1991; Zanchi et al., 2010). The folded Triassic and older series are preserved below double verging thrusts. The deformed rocks are overlain by the Middle Jurassic Kashafrud Formation characterized by its basal conglomerate (J2). D: Devonian, C: Carboniferous, PT: Permo-Triassic molassic sediments, T1 and T2: part of the Triassic series (see description in the text), T3a: Triassic Miankuhi Formation, J2: Conglomeratic base of the Middle Jurassic Kashafrud Formation and J3: Upper part of the Middle Jurassic Kashafrud Formation.

Figure 8: Seismic section showing the triangle structure to the NW of the Aghdarband erosional window (location on the Aghdarband cross-section, Figure 6). This seismic line shows two major North-directed basement thrusts that branch into an inferred detachment within the shales of the Campanian. For calibration, we used field data and information from the borehole represented $\mathrm{n}$ the figure. Legend of the horizons: Black = Top Trias; Dark blue $=$ top Kashafrud Formation (Middle Jurassic); Light blue = top Mozduran Formation (Upper Jurassic); Dark green = Top Shurijeh Formation (Neocomian); Green $=$ Top Aitamir Formation (Cenomanian); Light green = Top Kalat Formation (Uppermost Cretaceous); Orange $=$ Top Chehel Kaman Formation (Paleocene). 
Figure 9: a) Seismic section from the Gonbadli gas field area (location in Figure 5) showing large-scale basement uplift. The Jurassic structure is shown by opposite set of normal faults, some of which seem to preserve their original normal displacement. b) Zoom on the previous seismic transect with a flattening done at the top Middle Jurassic horizon which highlight of the Kashafrud half graben structures. Legend of the horizons: Purple = Top Trias; Dark blue = top Kashafrud Formation (Middle Jurassic); Light blue = top Mozduran Formation (Upper Jurassic); Dark green = Top Shurijeh Formation (Neocomian); Green $=$ Top Aitamir Formation (Cenomanian); Light green = Top Kalat Formation (Uppermost Cretaceous); Orange $=$ Top Chehel Kaman Formation (Paleocene).

Figure 10: Seismic section across the Khangiran gas field extracted from a 3D cube. The Khangiran structure is due to the Tertiary inversion of a Middle Jurassic half graben. The occurrence of growth strata within the Oligocene-Neogene sequences highlights that the graben inversion is associated to the Alpine tectonic phase as a consequence of an inversion tectonics. The black arrow highlights some carbonate build-ups within the Upper Jurassic Mozduran limestones. Legend of the horizons: Purple = Top Trias; Dark blue $=$ top Kashafrud Formation (Middle Jurassic); Light blue = top Mozduran Formation (Upper Jurassic); Dark green = Top Shurijeh Formation (Neocomian); Green = Top Aitamir Formation (Cenomanian); Light green = Top Kalat Formation (Uppermost Cretaceous); Orange $=$ Top Chehel Kaman Formation (Paleocene); Yellow = Intra Oligo-Neogene conglomerates.

Figure 11: The Darre Gaz regional cross-section (see location in Figure 5) shows the inversion of Middle Jurassic front of the belt is characterized by North-verging basement thrusts that mostly branch into a major detachment within the Aptian-Albian series. 
Figure 12: Seismic section showing typical structures of the Darre Gaz area with a disharmony between deep and surface structures implying several dcollement levels within the Cretaceous series. The deeper horizons of this section are not calibrated. Legend of the horizons: Black = Top Trias; Dark blue = top Kashafrud Formation (Middle Jurassic); Light blue = top Mozduran Formation (Upper Jurassic); Dark green = Top Shurijeh Formation (Neocomian); Green = Top Aitamir Formation (Cenomanian); Light green = Top Kalat Formation (Uppermost Cretaceous); Orange = Top Chehel Kaman Formation (Paleocene).

Figure 13: The western regional cross-section (see location in Figure 5) highlights the upper basement décollement level forming double-verging structures that cross-cut the Middle Jurassic rift system. This cross-section also shows two folded unconformities: at the base of the Lower Cretaceous and at the base of the post-Eocene sediments.

Figure 14: Scheme of several fields observations highlighting the structural relationships between the different stratigraphic formations. The important thickness variations of the Middle Jurassic Kashafrud Formation is due to active rifting during deposition. An erosional surface at the base of the Late Jurassic Chaman Bid Formation and several progradations of the Upper Jurassic Mozduran limestones into the marls of the Late Jurassic Chaman Bid Formation are observed. Notice the reduced thickness of Cretaceous and Tertiary series. 
Figure 15: The Gorgan Plain regional cross-section (see location in Figure 5) shows the buried folds of the Kopet Dagh beneath the thick post-Eocene sediments belonging to the South Caspian Sea Basin. This cross-section has mainly been constructed from seismic sections.

Figure 16: Seismic section below the Gorgan Plain to the Western part of the Kopet Dagh. This section shows the folded structures overlain by a major unconformity with progressive onlap above this unconformity. The pink horizon near the top of the section corresponds to the top of the Mid-Pleistocene strata, the red horizon corresponds to the Late-Eocene and Early Oligocene unconformity, the green horizons correspond to the Late Cretaceous marls and clastic sediments. Within the syncline, it is possible that the Paleogene up to the Upper Eocene were preserved. (a) Folded and faulted structures, the folds are oriented NE-SW parallel to the orientation of the western part of the Kopet Dagh belt (b) The red line corresponds to the folded unconformity at the base of the Oligocene-Neogene strata. 
Figure 17: Seismic profile of the margin of the Caspian Sea Basin below the Gorgan Plain. Notice the unconformity highlighted in red which is covered by sediments of the South Caspian Sea Basin. A shale ridge structure is marked in red (M?) suggesting that the sediments just on top of the unconformity are probably made of the Oligocene Maykop Formation. The pink horizon corresponds to the near top Mid-Pleistocene, the yellow horizon corresponds to the near top Miocene, the red horizon corresponds to the Late Eocene-Early Oligocene unconformity and the green horizons correspond to the Late Cretaceous.

Figure 18: Schematic reconstructions of the geodynamic settings of the region centered on Central Iran during a) the Late Triassic to the Early Jurassic; b) the Middle Jurassic; c) the latest Jurassic to the Early Cretaceous and d) the Late Cretaceous to the Eocene. Reconstructions for the Neotethys and Iran were adapted from Agard et al. (2011); Barrier and Vrielynck (2008).

Figure 19: Schematic reconstructions of the geodynamic settings of the region centered on Central Iran during a) the Late Eocene to the Early Oligocene; b) the Oligocene to the Middle Pliocene and c) the Late Pliocene to the present-day. Reconstructions for the Neotethys and Iran were adapted from Agard et al. (2011); Barrier and Vrielynck (2008). 
Figure 1

Click here to download high resolution image
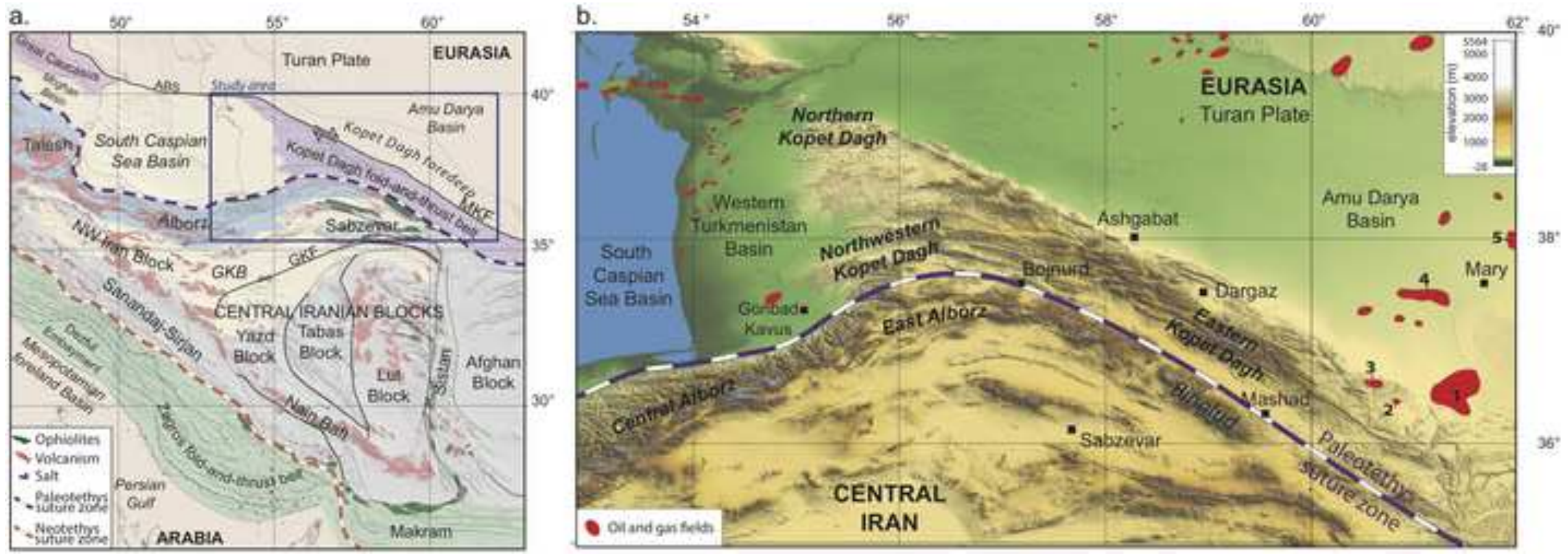
Figure 2

Click here to download high resolution image

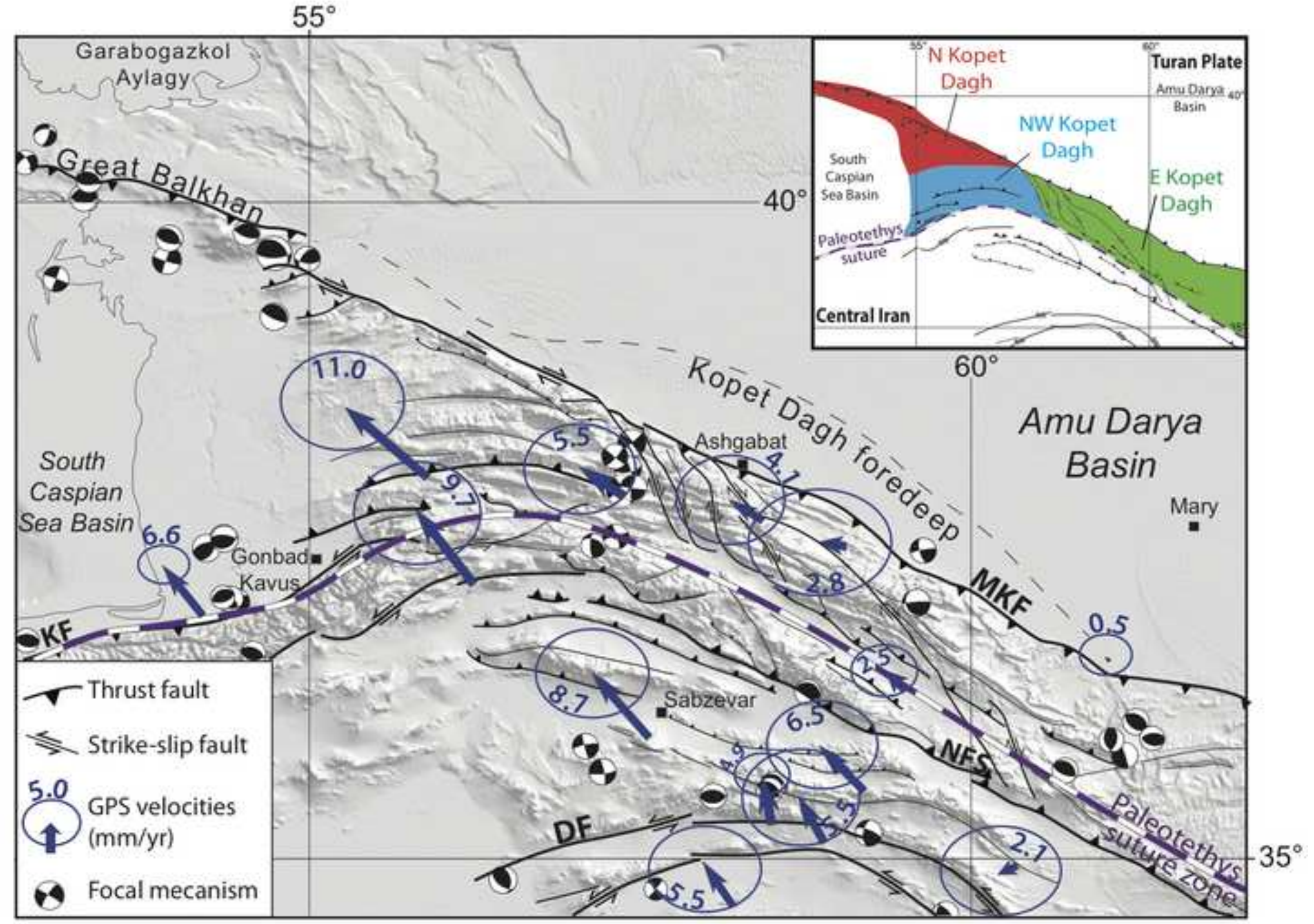




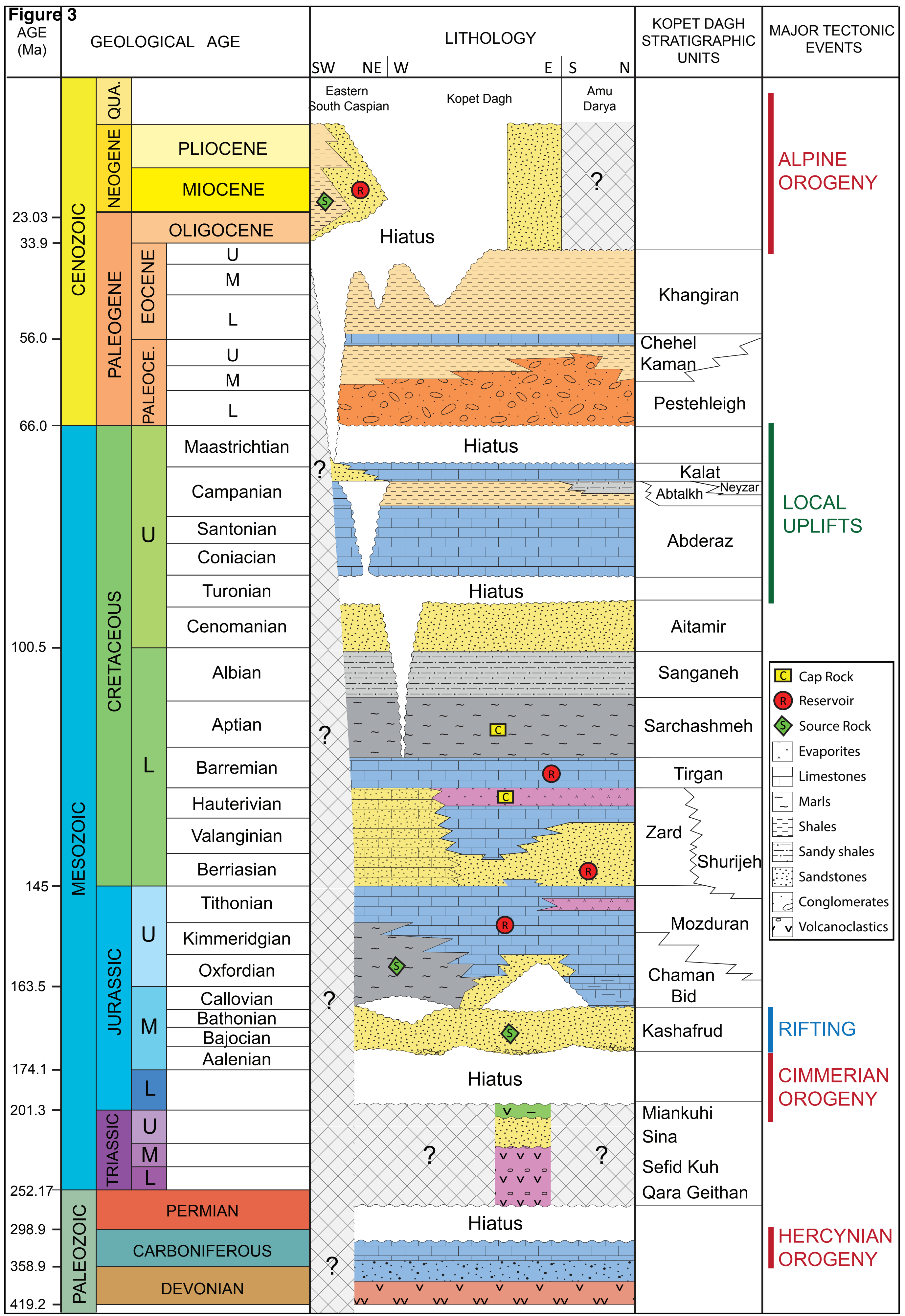


Figure 4

Click here to download high resolution image

a) $\mathrm{W}$

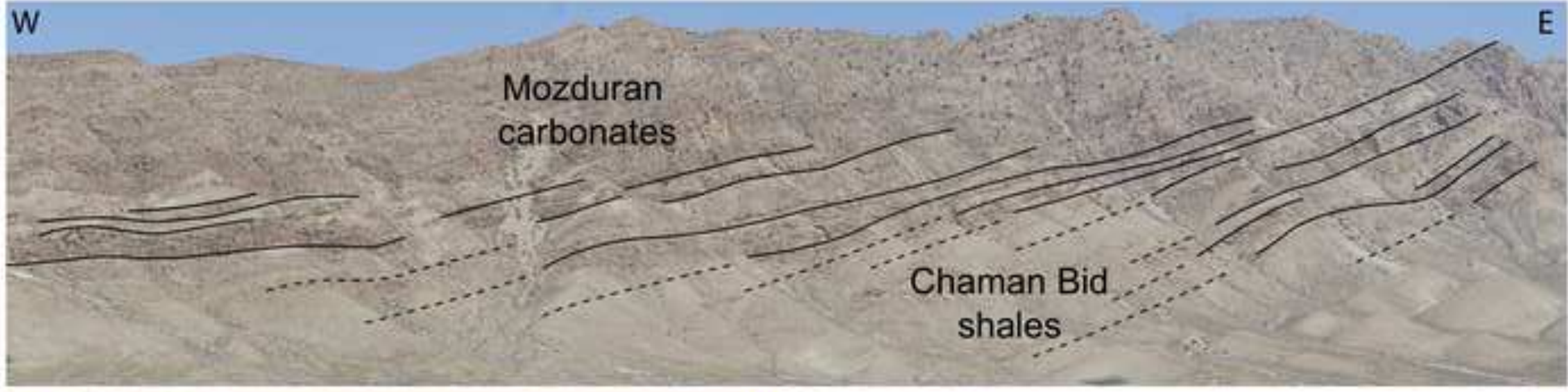

b)
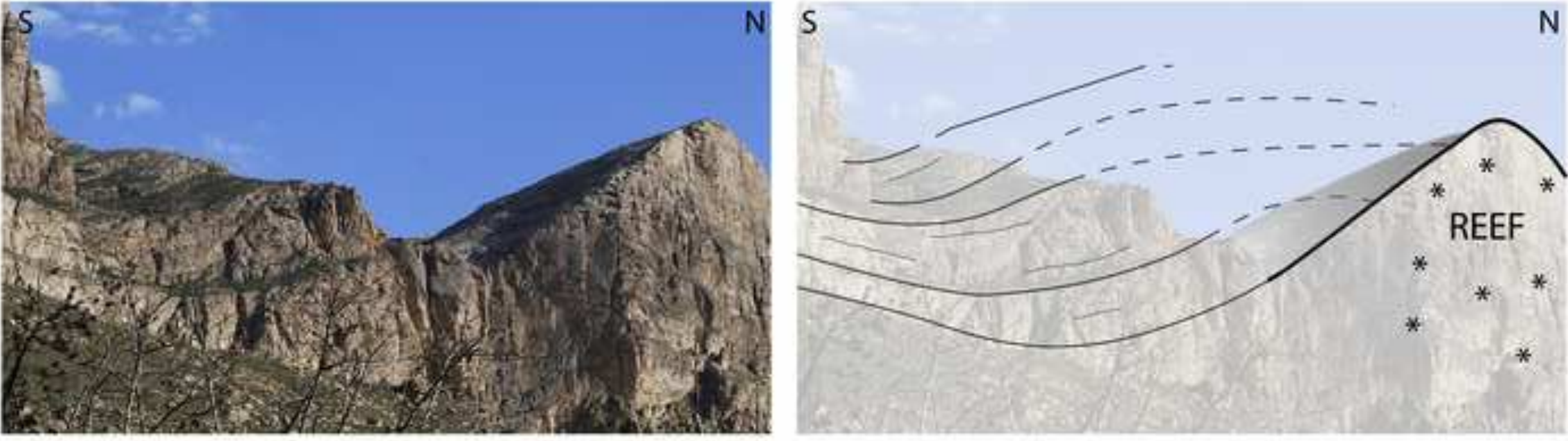


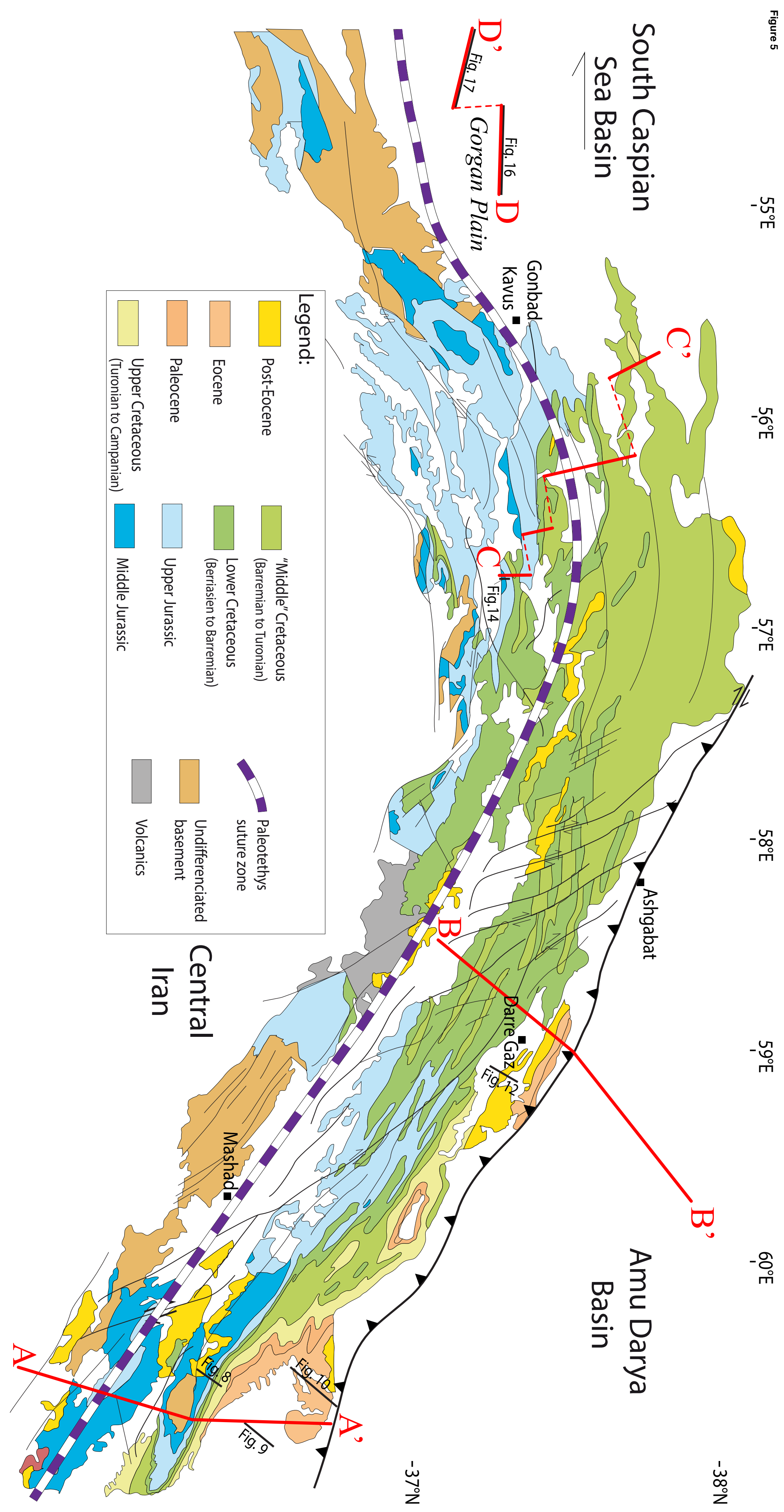


Figure 6

Click here to download high resolution image

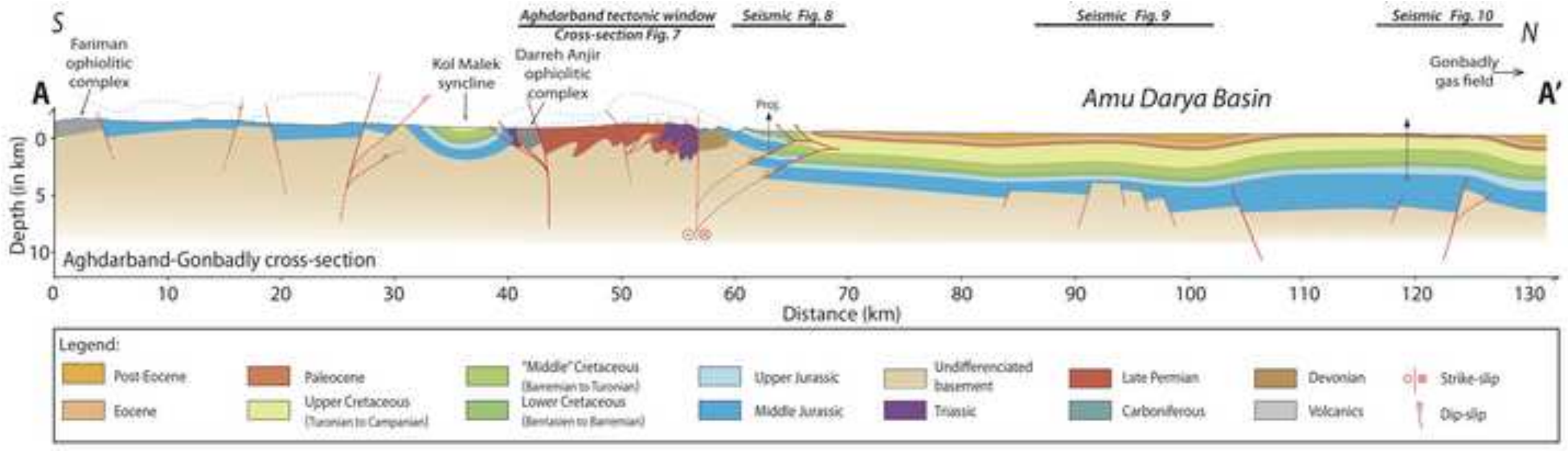




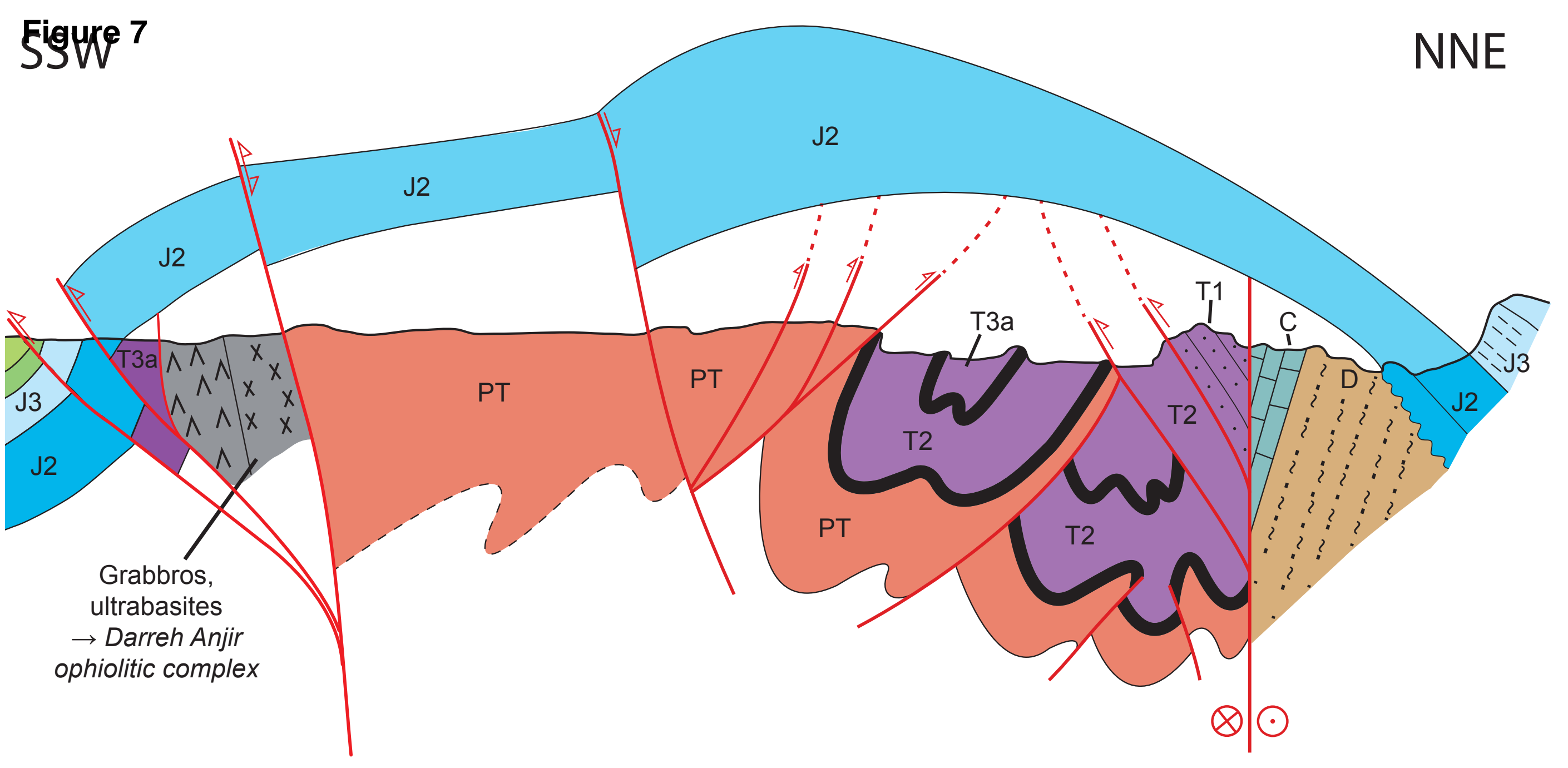




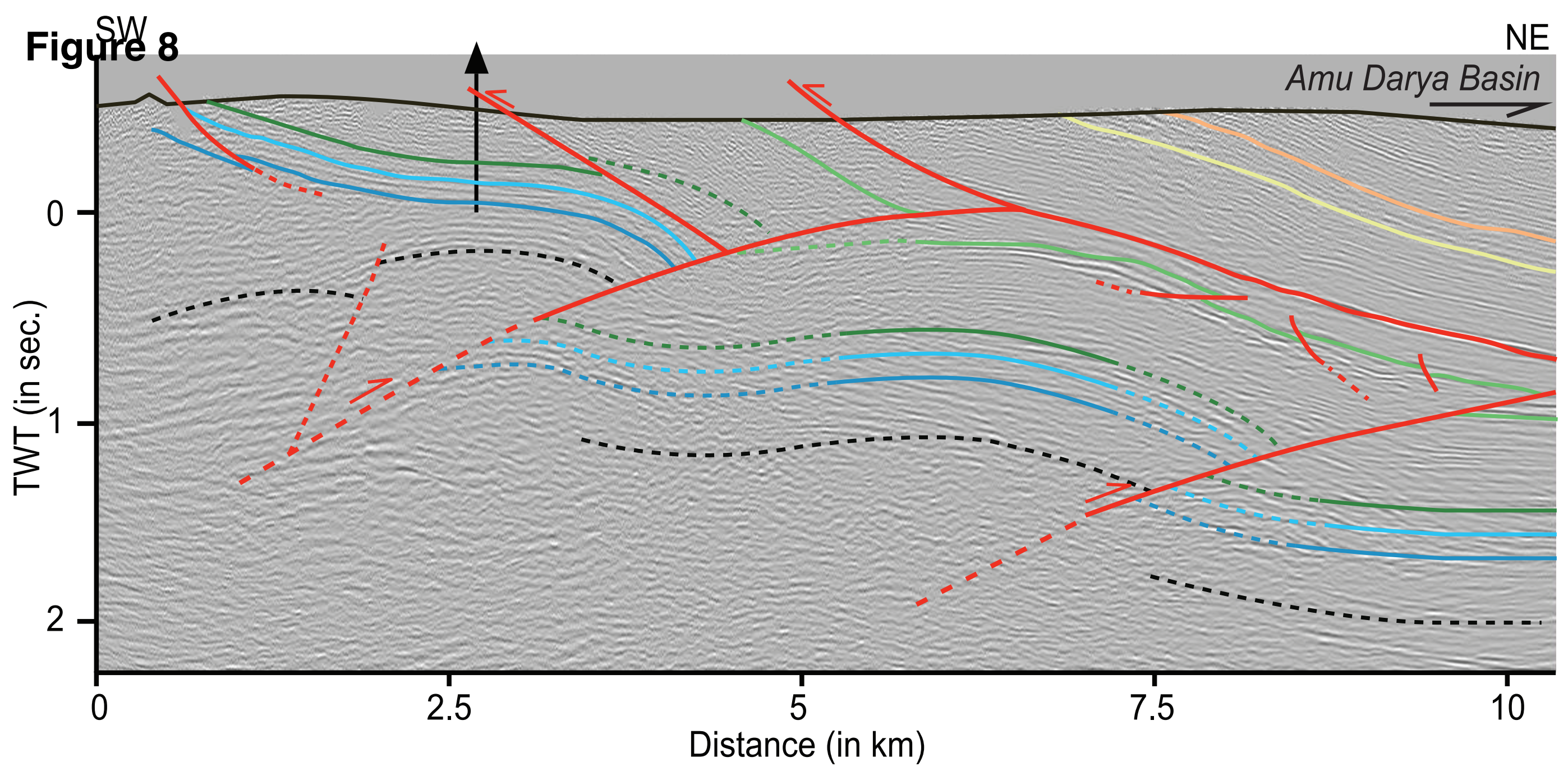




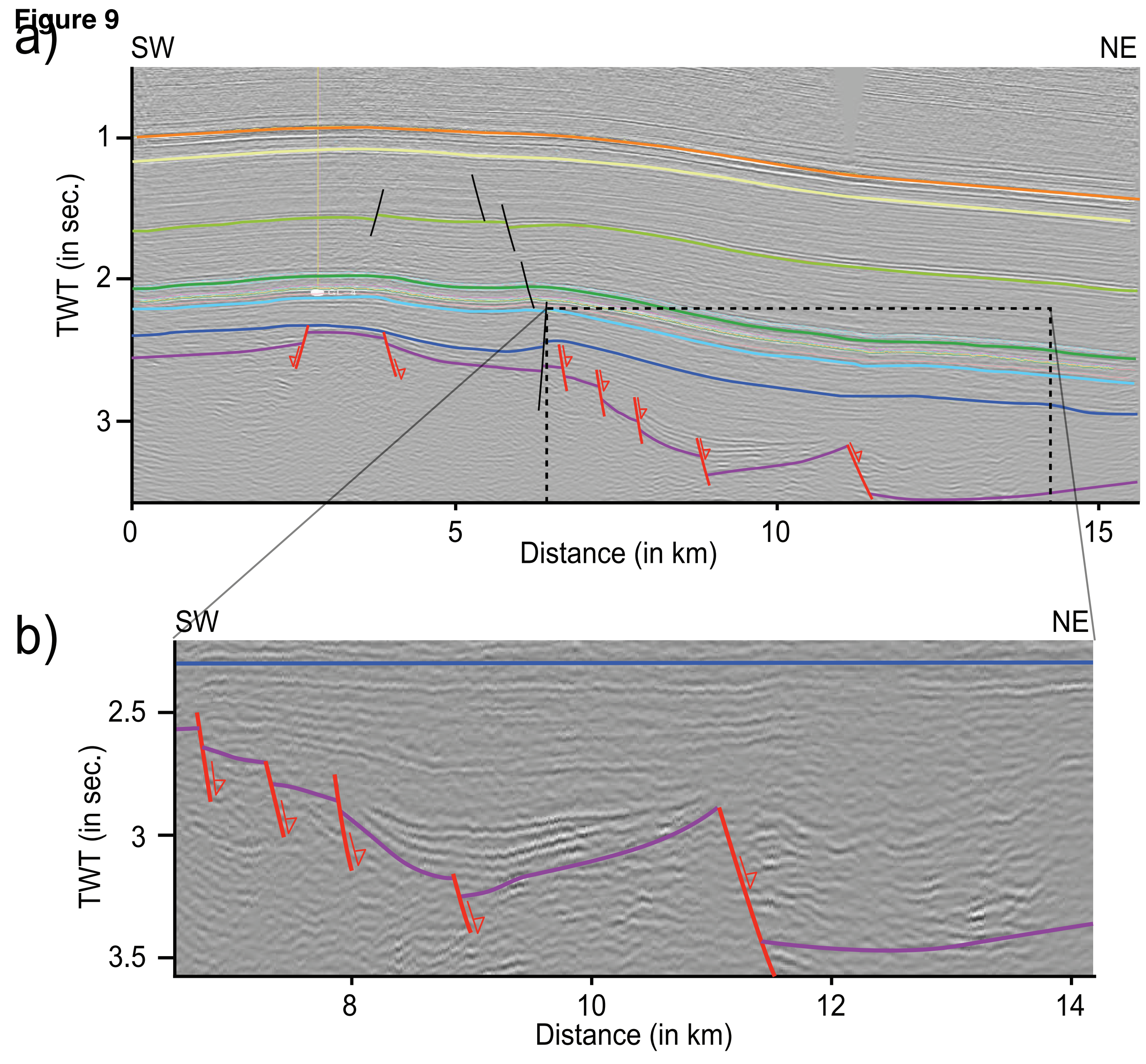




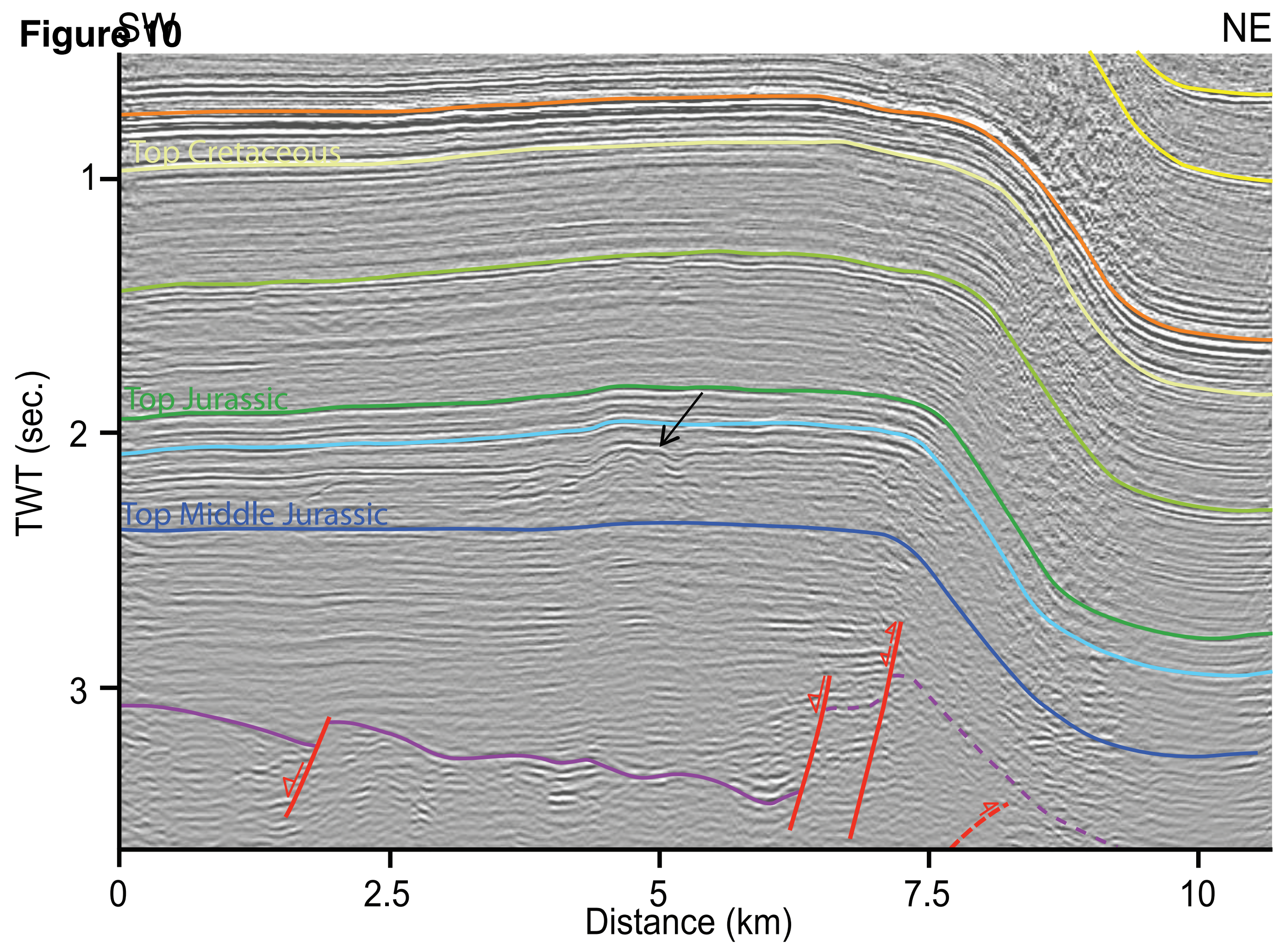




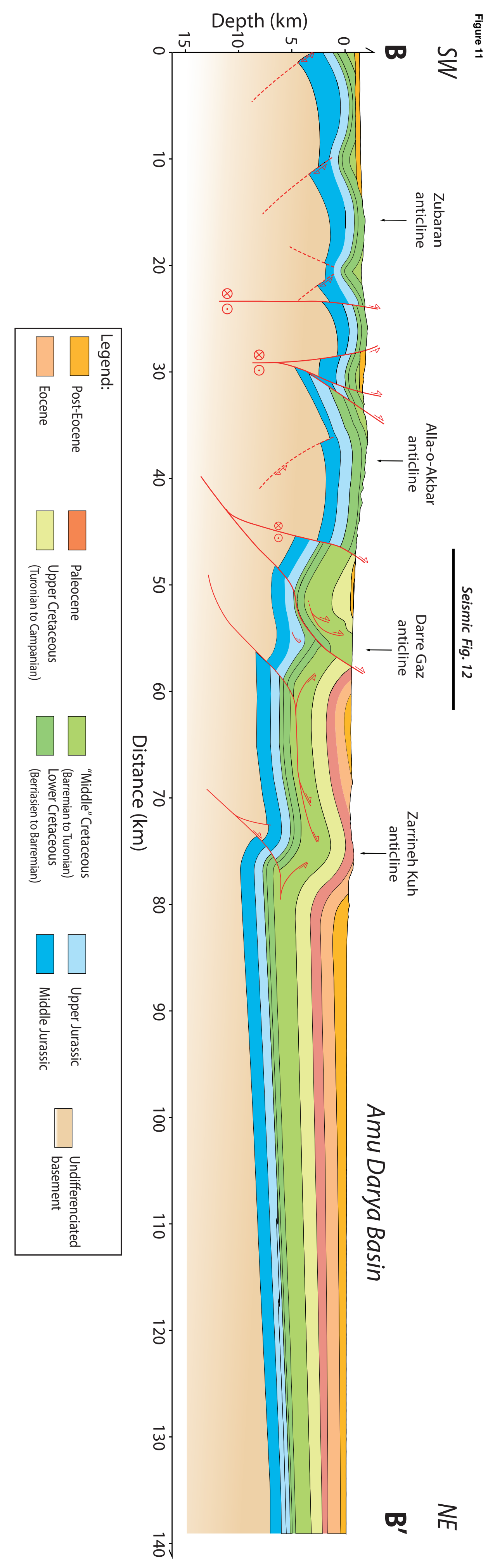


Figurght

NE

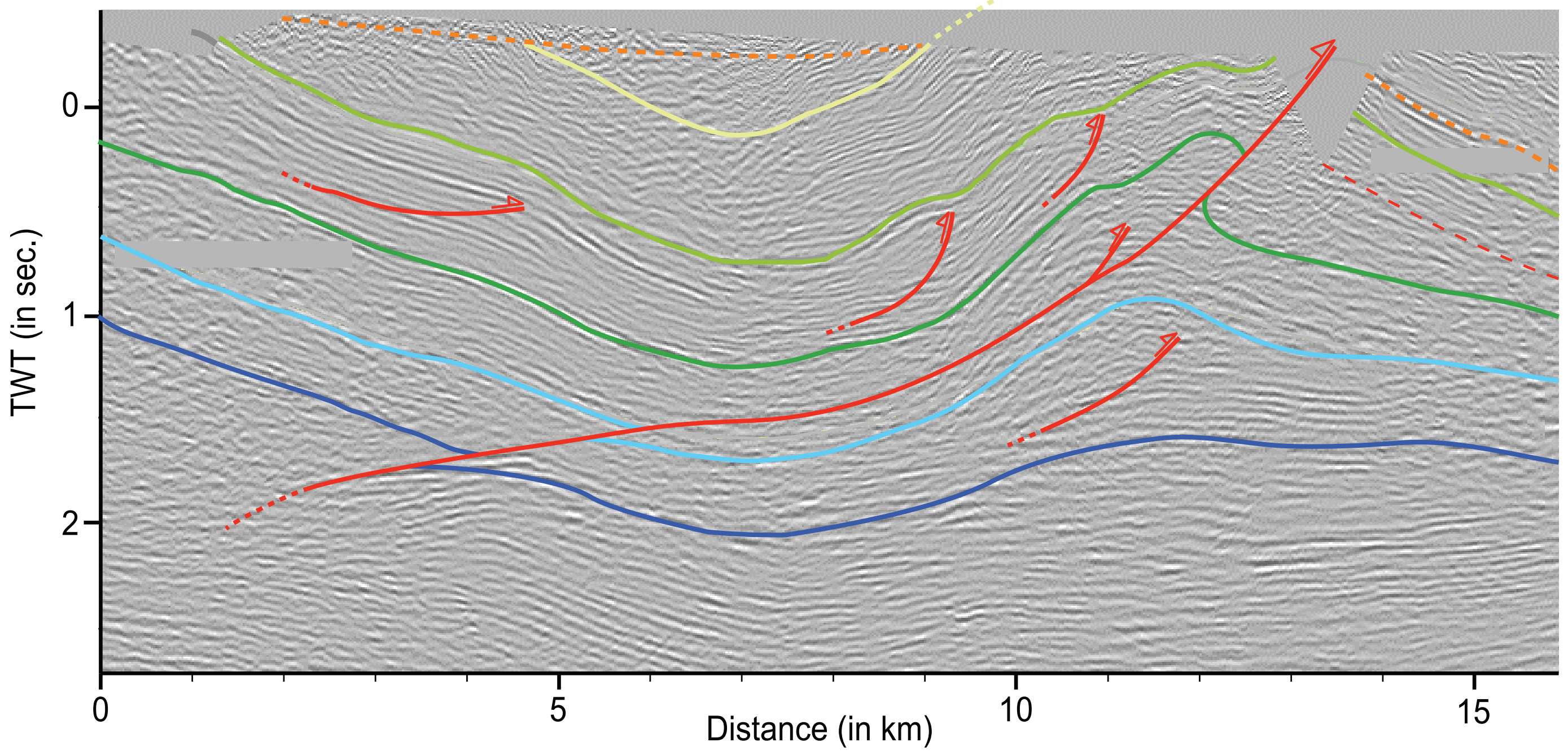




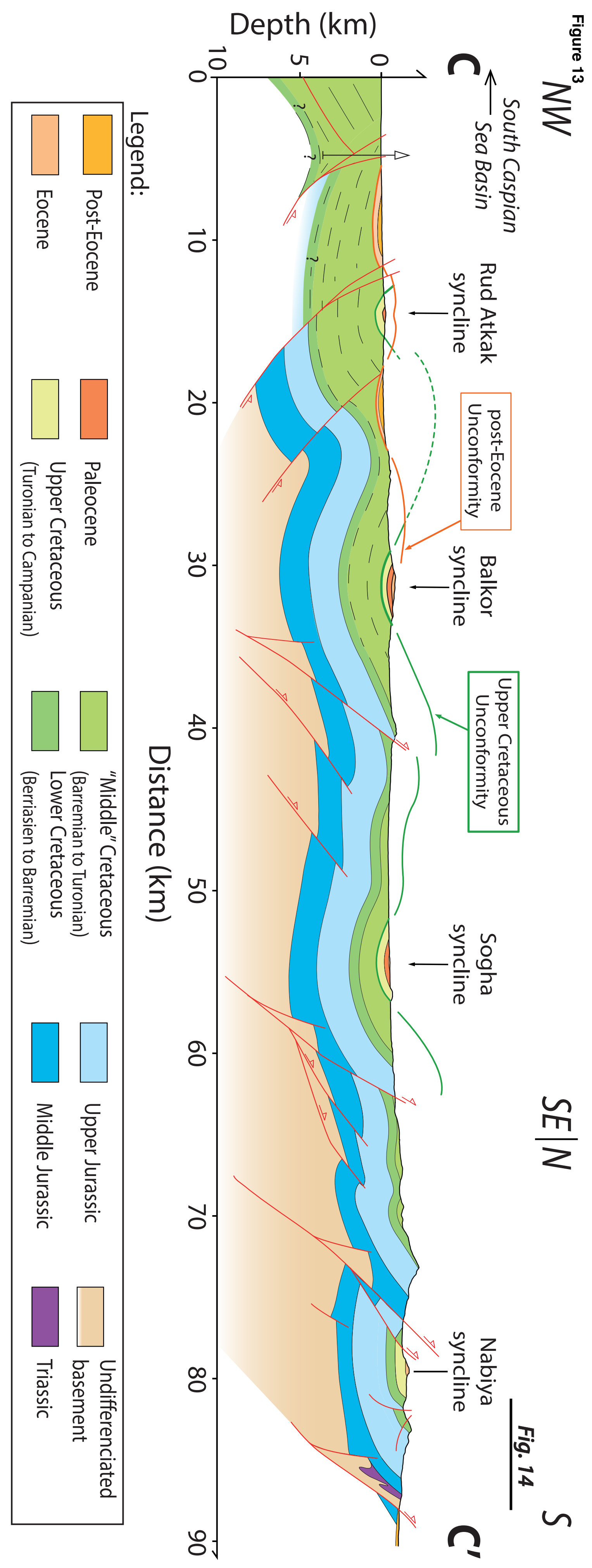


Figure 14 Pestehleigh Khangiran

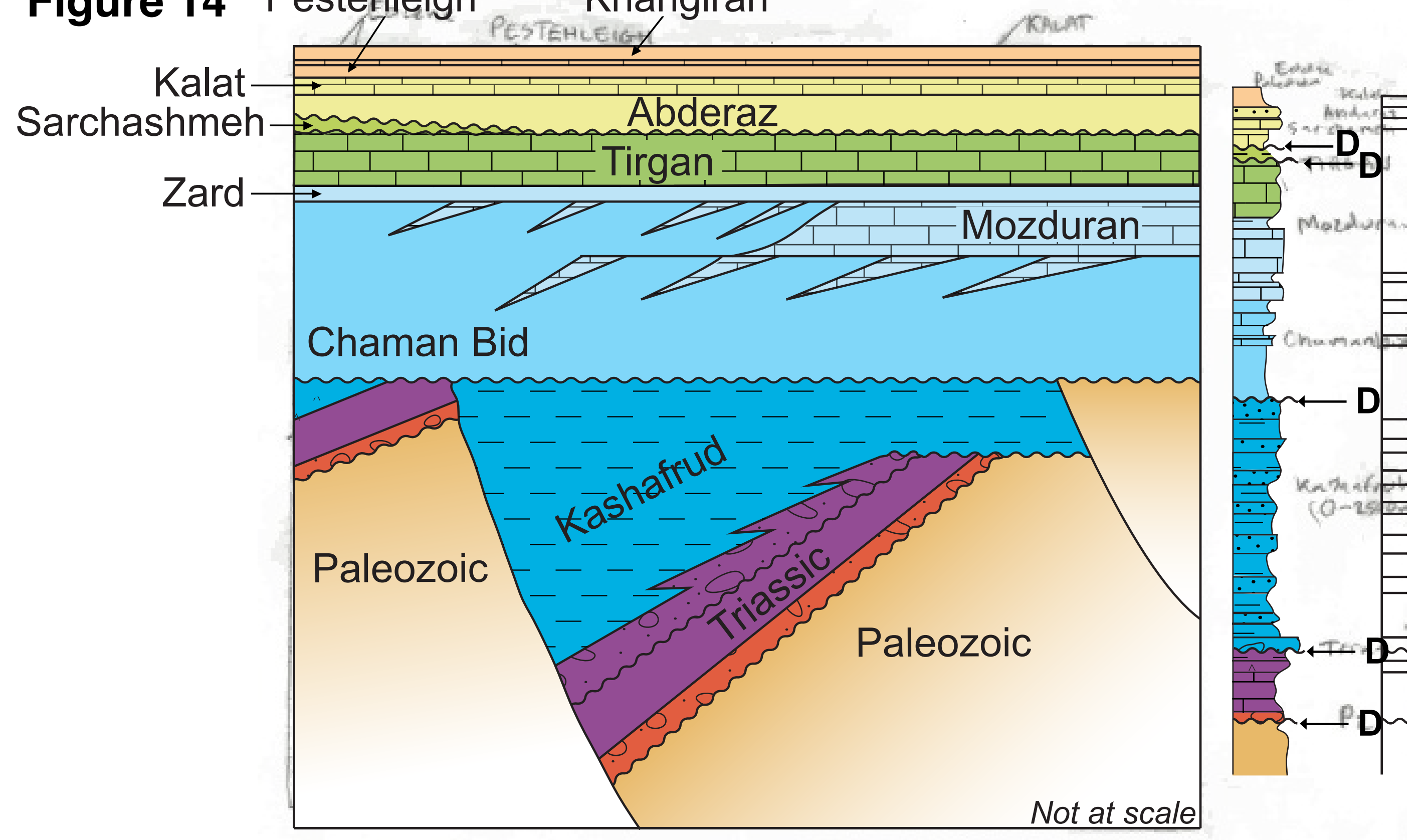




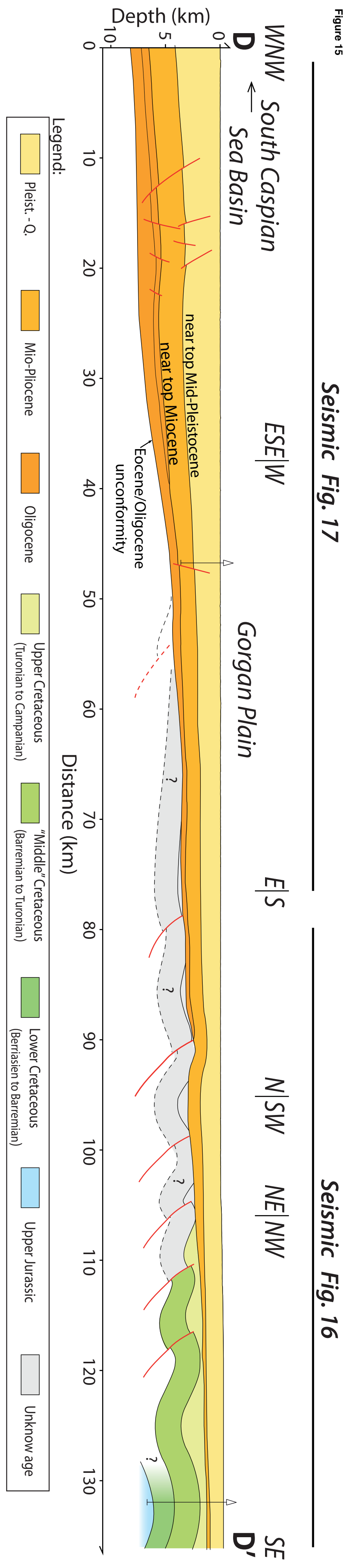




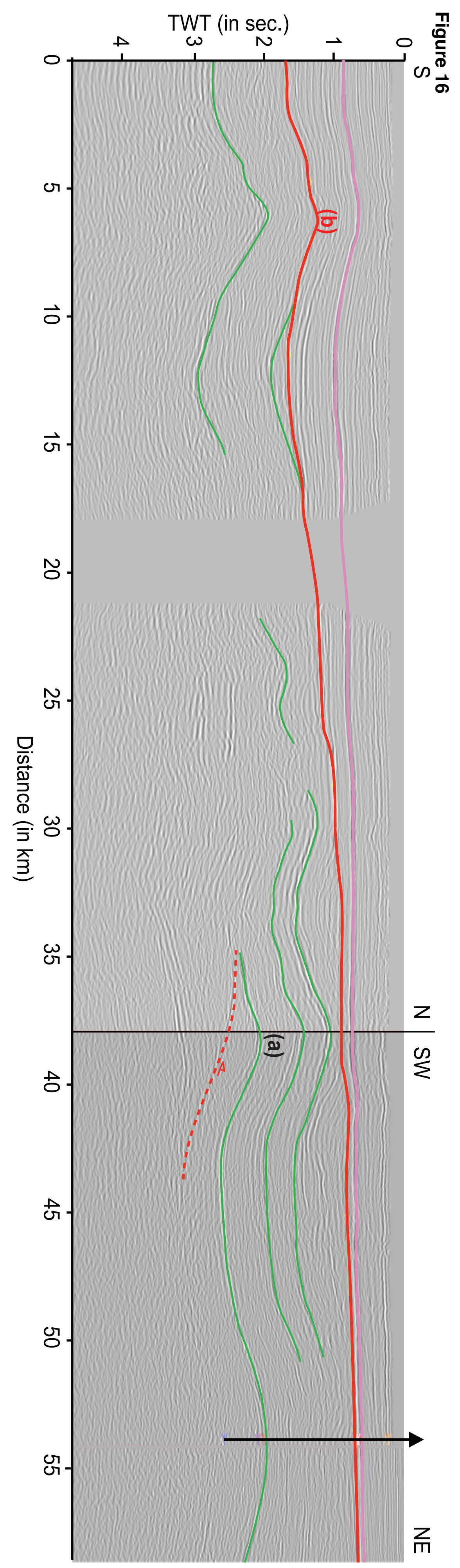




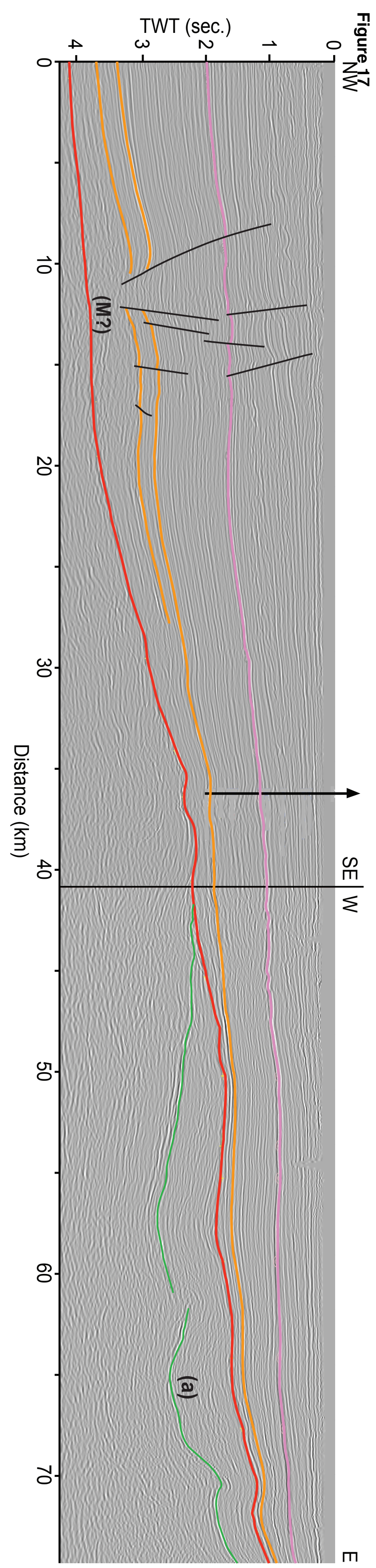




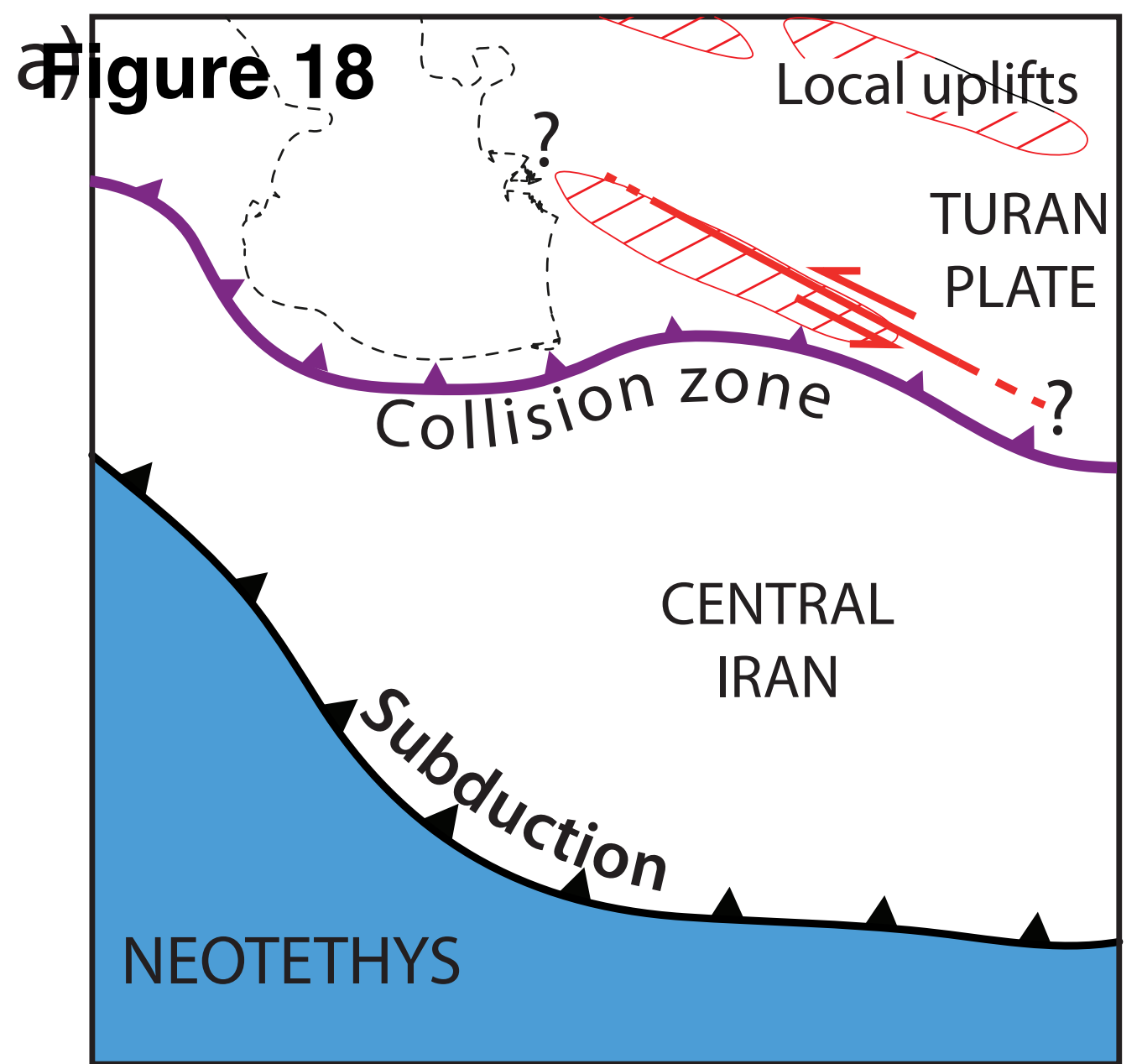

Late Triassic - Early Jurassic

c)

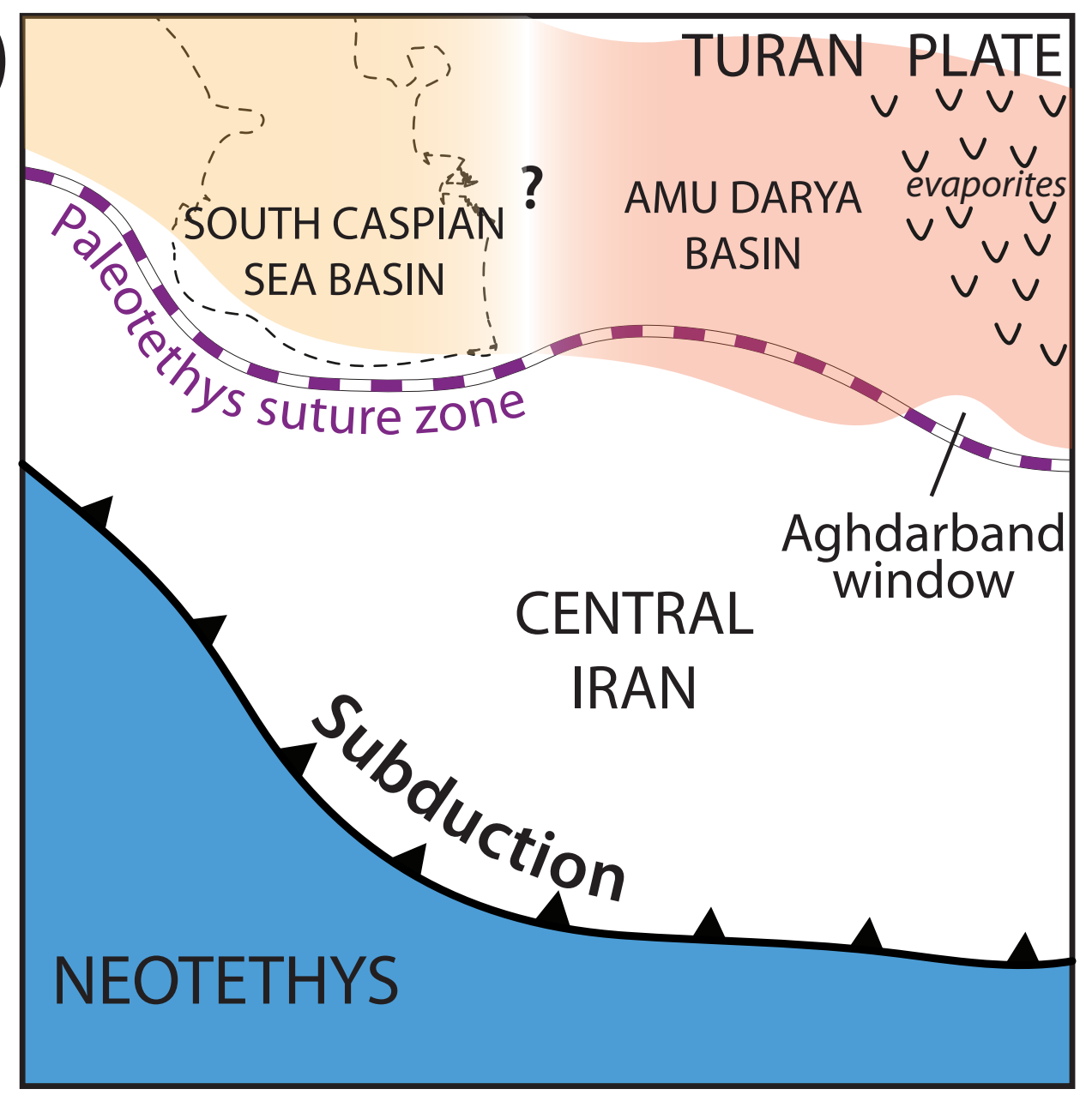

Latest Jurassic - Early Cretaceous b)

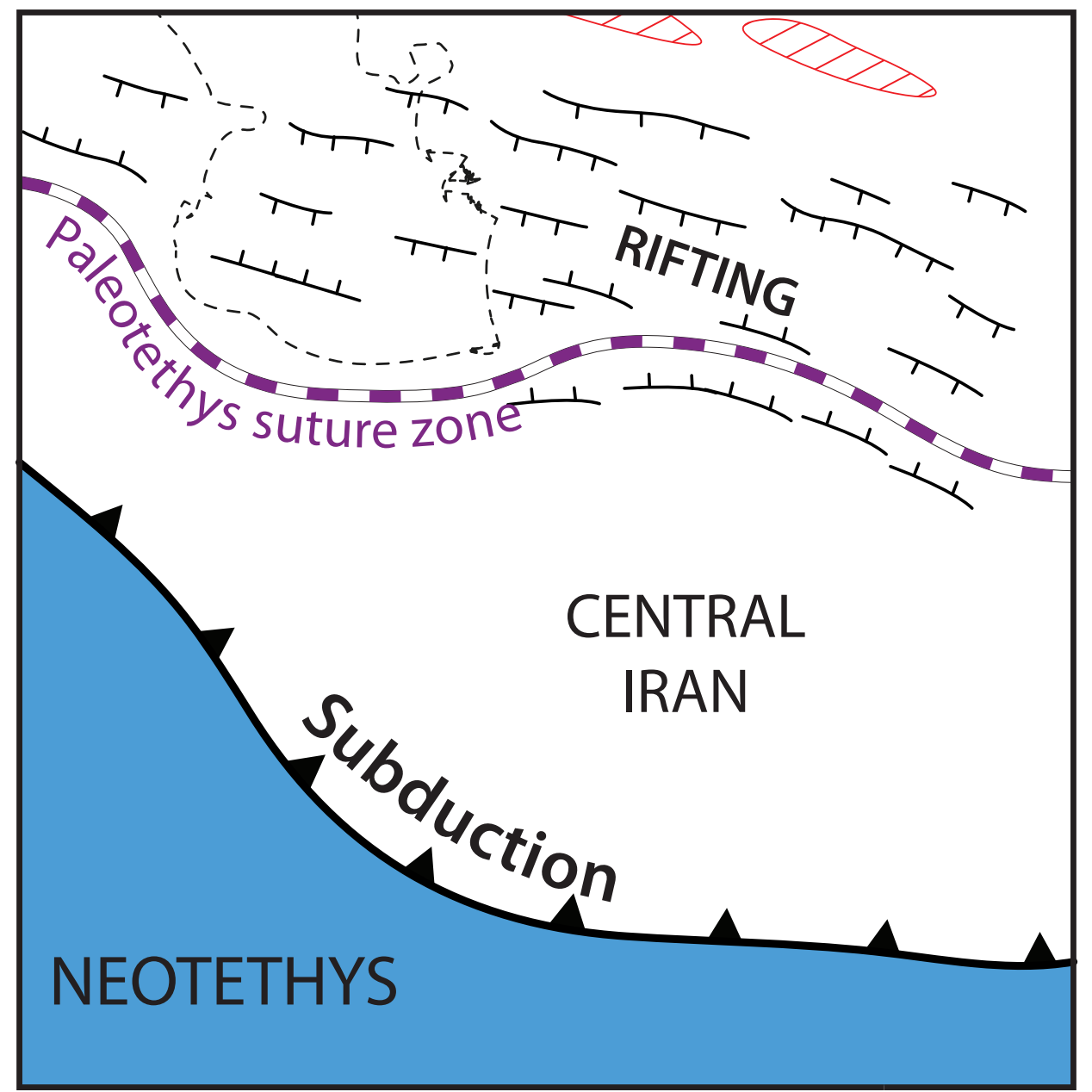

Middle Jurassic

d)

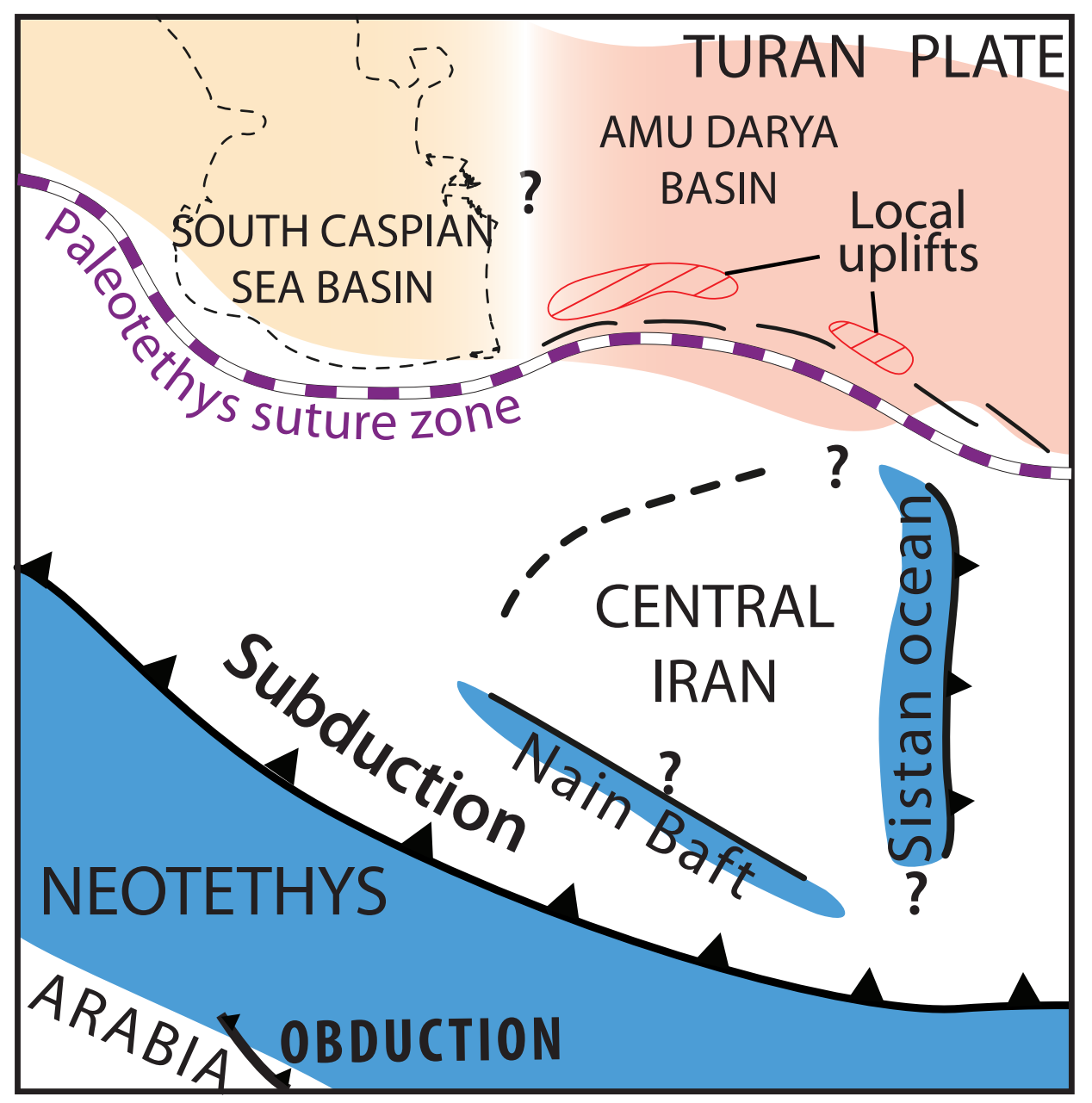

Late Cretaceous - Eocene 


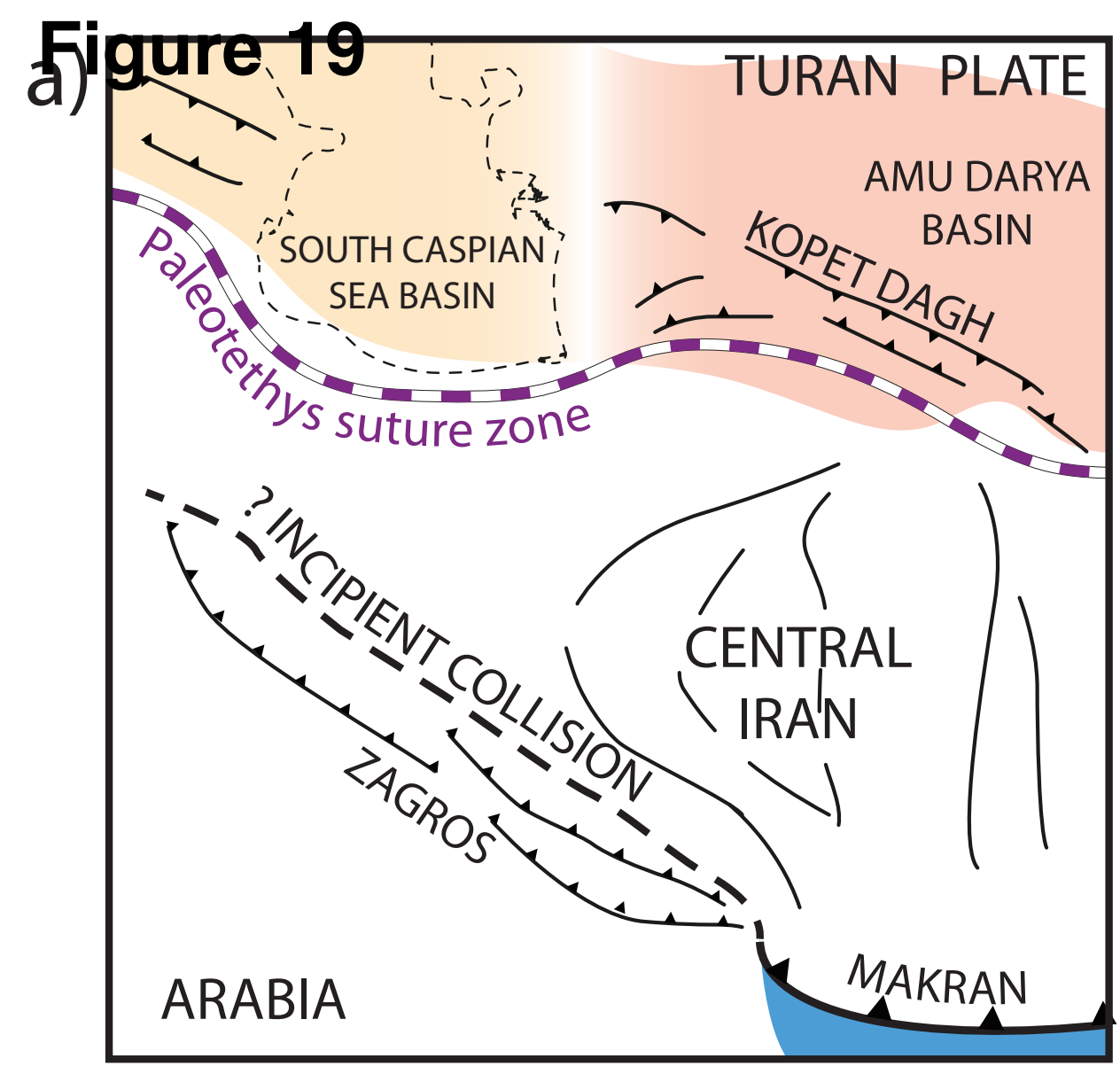

Late Eocene - Early Oligocene b)

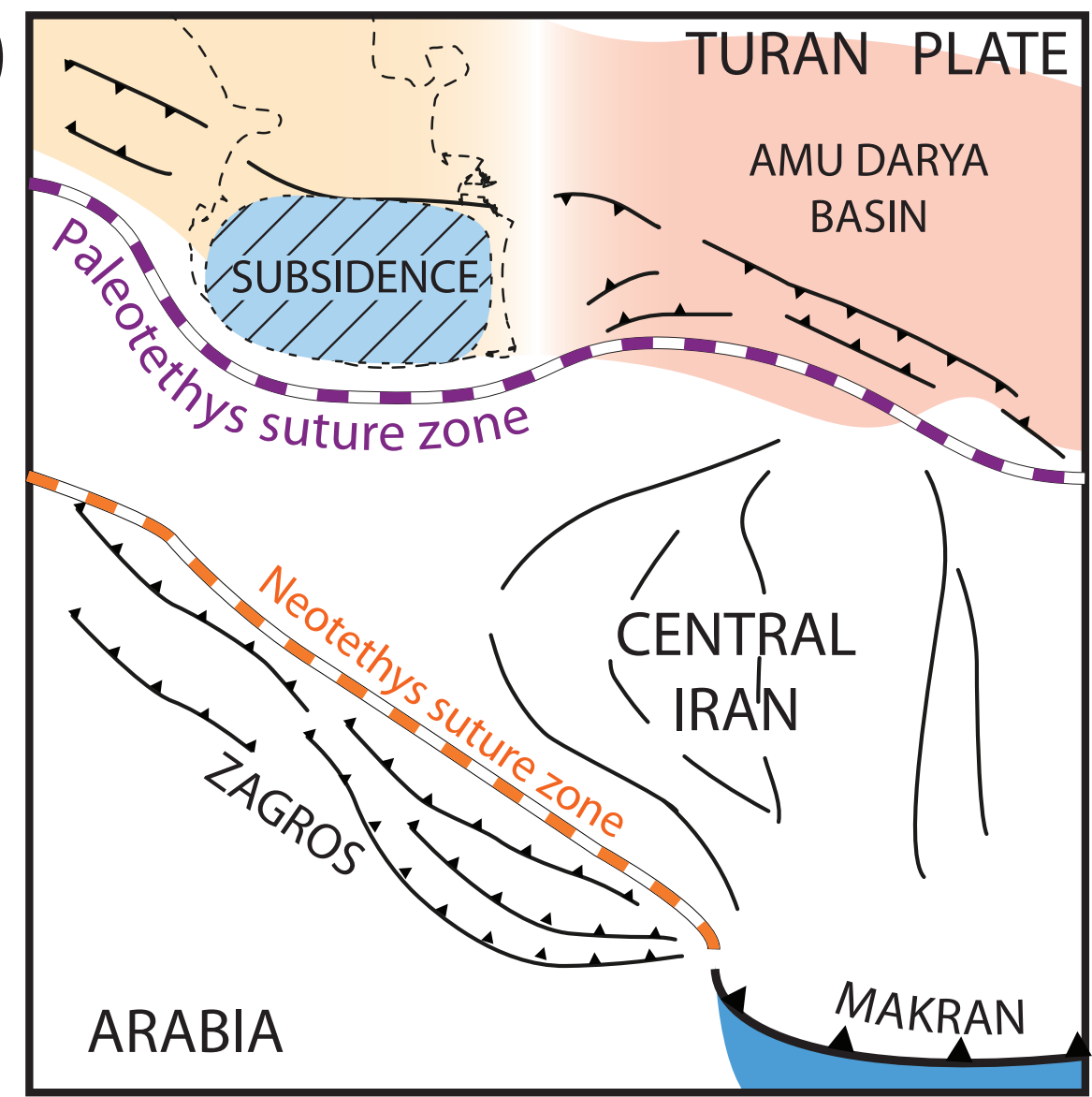

Oligocene - Middle Pliocene

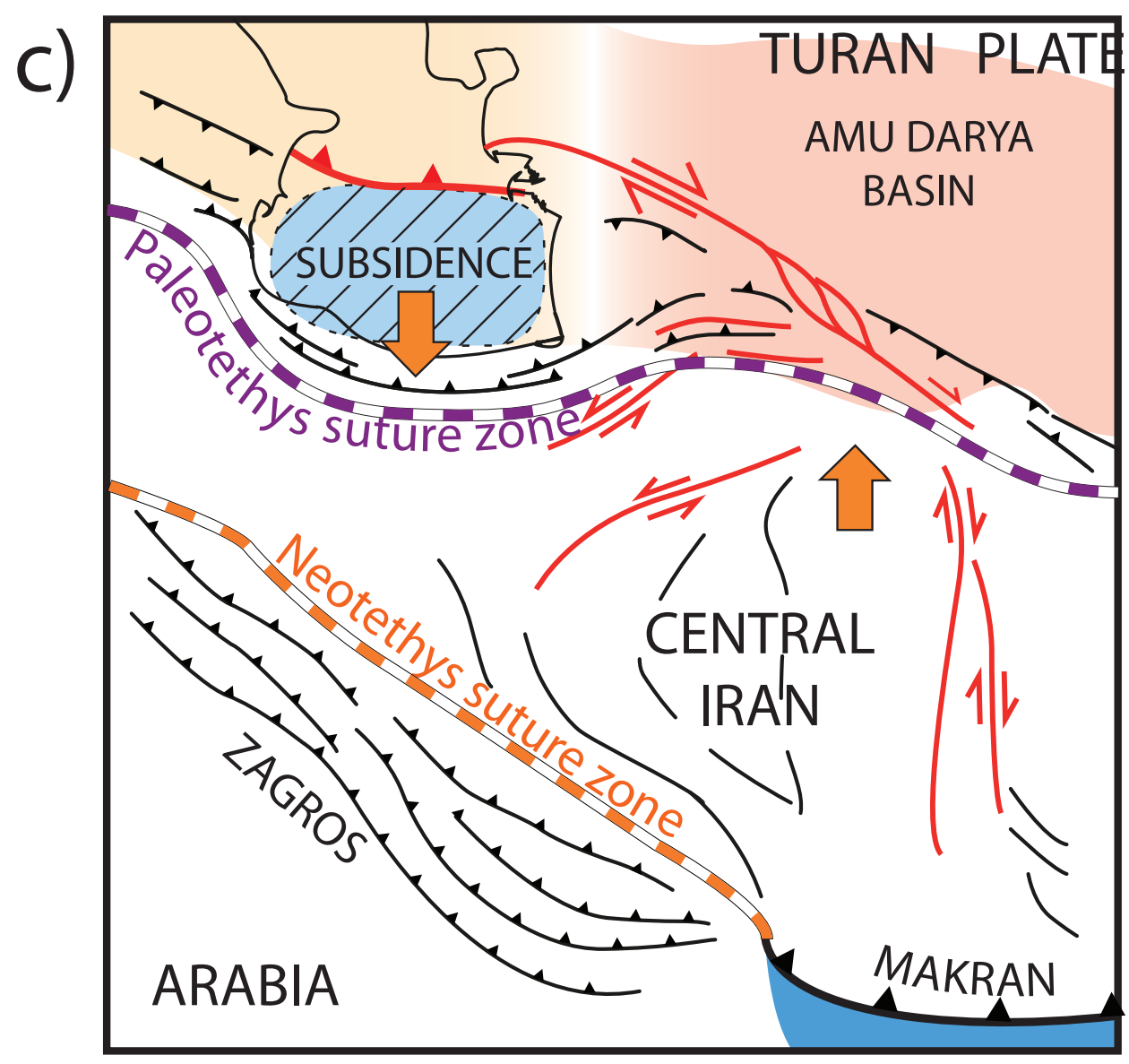

Late Pliocene - Present 
Table 1

\begin{tabular}{|c|c|c|c|c|c|c|c|c|}
\hline$\stackrel{\frac{\pi}{4}}{\frac{1}{4}}$ & \begin{tabular}{|l|} 
\\
$\frac{0}{2}$ \\
2 \\
2
\end{tabular} & 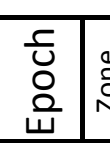 & 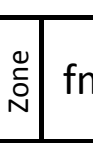 & $\mathrm{m}$ & Sample reference & $\begin{array}{l}\text { Sample } \\
\text { location }\end{array}$ & Lithology & Observed Nannofossils \\
\hline \multirow{9}{*}{ 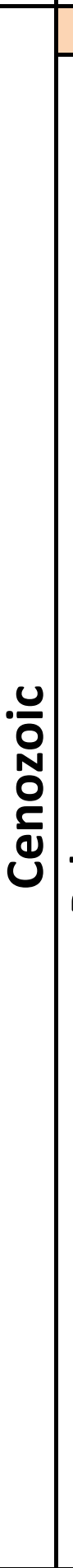 } & \multirow{2}{*}{\multicolumn{2}{|c|}{ 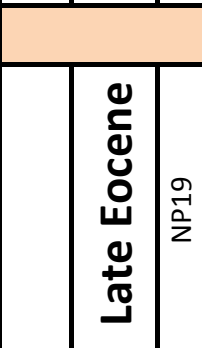 }} & \multicolumn{6}{|c|}{ ?Oligocene-Neogene conglomerates } \\
\hline & & & \multirow{5}{*}{\multicolumn{2}{|c|}{$\begin{array}{l}\frac{c}{0} \\
\frac{\sqrt{0}}{00} \\
\frac{0}{0} \\
\frac{\pi}{2}\end{array}$}} & $\begin{array}{l}184 A R \\
185 A R \\
186 A R\end{array}$ & 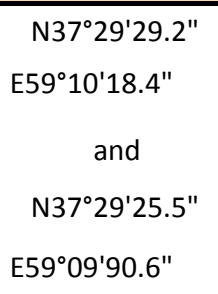 & $\begin{array}{c}\text { Marl with } \\
\text { thin limestone beds }\end{array}$ & \\
\hline & \multirow{4}{*}{ 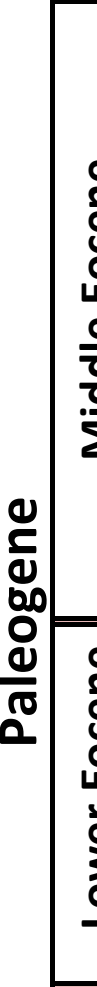 } & \multirow{3}{*}{ 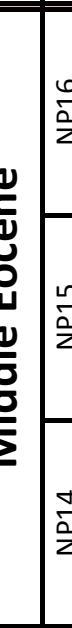 } & & & \begin{tabular}{|c|}
$10-318$ \\
$10-322$ to 324 \\
$12-104 \quad 12-119$ \\
$181 A R-182 A R$ \\
\end{tabular} & 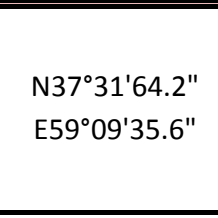 & $\begin{array}{l}\text { Marl with } \\
\text { thin limestone and } \\
\text { sandy beds }\end{array}$ & $\begin{array}{l}\text { R. umbilica } \\
\text { Ch. solitus } \\
\text { D. tassi nodifus } \\
\text { D. roemmilensis } \\
\end{array}$ \\
\hline & & & & & $\begin{array}{l}10-145 \\
10-146\end{array}$ & & $\begin{array}{c}\text { Marl with } \\
\text { thin limestone beds }\end{array}$ & $\begin{array}{l}\text { Ch. gigas } \\
\text { Ch. solitus } \\
\text { N. alatus } \\
\text { S. bifurcatoides }\end{array}$ \\
\hline & & & & & $10-139$ to $10-144$ & & $\begin{array}{c}\text { Marl with } \\
\text { thin limestone beds }\end{array}$ & $\begin{array}{l}\text { D. sublodoensis } \\
\text { D. chiastolithus } \\
\text { D. nonaradiatus } \\
\text { D. kuepperi } \\
\end{array}$ \\
\hline & & 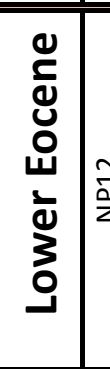 & & & $\begin{array}{c}12-135 \text { to } 12-140 \\
178 A R\end{array}$ & 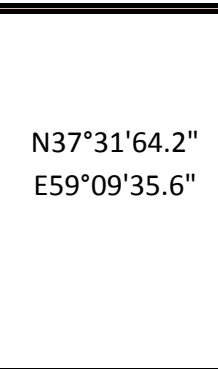 & $\begin{array}{l}\text { Limestone with marl } \\
\text { intercalated often } \\
\text { dolomitized }\end{array}$ & $\begin{array}{l}\text { D. lodoensis } \\
\text { M. tribrachiatus } \\
\text { S. radians } \\
\text { T. pulcherima } \\
\text { Ch. Solitus } \\
\text { D. binodosus } \\
\text { L. nascens }\end{array}$ \\
\hline & & 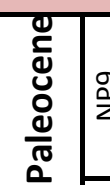 & \multirow{2}{*}{\begin{tabular}{|l|}
$\frac{0}{2}$ \\
$\frac{1}{2}$ \\
$\frac{0}{2}$
\end{tabular}} & \multirow{2}{*}{ 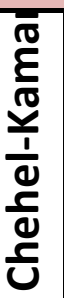 } & $\begin{array}{l}10-103 \\
10-104\end{array}$ & & \multirow{2}{*}{$\begin{array}{l}\text { White limestone and } \\
\text { light marls }\end{array}$} & $\begin{array}{l}\text { D. multiradiatus } \\
\text { F. tympaniformis } \\
\text { H. kleinpellii } \\
\end{array}$ \\
\hline & & 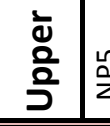 & & & $10-111$ & $\begin{array}{l}\text { N36 } 177^{\prime 2} 23.2^{\prime \prime} \\
\mathrm{E} 66^{\circ} 35^{\prime} 29.4^{\prime \prime}\end{array}$ & & $\begin{array}{l}\text { Ch. danicus } \\
\text { F. tympaniformis }\end{array}$ \\
\hline & & 这 & 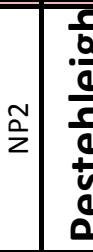 & 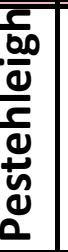 & $10-108$ & $\begin{array}{l}\text { N36 } 177^{\prime} 23.2^{\prime \prime} \\
\text { E66 } 35^{\circ} 29.4^{\prime \prime}\end{array}$ & $\begin{array}{c}\text { Continental red } \\
\text { sandstone and } \\
\text { siltstones - Some } \\
\text { conglomerates with } \\
\text { short marine } \\
\end{array}$ & $\begin{array}{l}\text { C. pelagicus } \\
\text { B. sparsus } \\
\text { Cr. Tenuis } \\
\text { E. subpertusa }\end{array}$ \\
\hline & \multirow{4}{*}{ 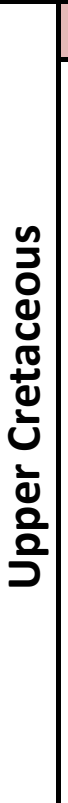 } & \multirow{4}{*}{ 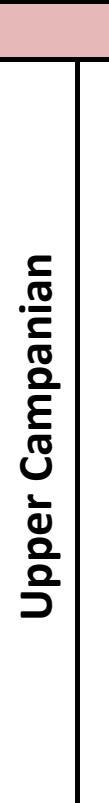 } & & & & Maastri & htian : GAP & \\
\hline & & & & $\frac{\underline{\pi}}{\frac{\pi}{\pi}}$ & $\begin{array}{c}10-41 \\
10-43 \text { to } 45 \\
11-253 \text { to } 257\end{array}$ & $\begin{array}{l}\text { N36 } 177^{\prime} 36.6^{\prime \prime} \\
\text { E60 } 33^{\circ} 21.6^{\prime \prime}\end{array}$ & $\begin{array}{l}\text { Massive limestone, } \\
\text { limestone with } \\
\text { rudists marls + } \\
\text { lumachelles beds } \\
\end{array}$ & $\begin{array}{l}\text { Q. quadratugohicus } \\
\text { Q. quadratrifidus } \\
\text { B. borinsoniatarca } \\
\text { E. eximius }\end{array}$ \\
\hline & & & & 采 & $\begin{array}{l}10-147 \text { to } 150 \\
11-315 \\
12-21 \text { to } 26\end{array}$ & 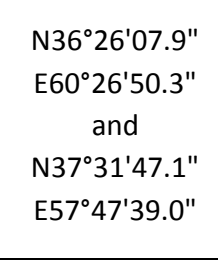 & Marl & \multirow{2}{*}{$\begin{array}{l}\text { B. parca } \\
\text { E. eximius } \\
\text { R. anthophorus } \\
\text { Q. gothicum } \\
\text { Q. trifidum }\end{array}$} \\
\hline & & & & $\begin{array}{l}\frac{N}{0} \\
\frac{\pi}{20} \\
\frac{0}{2} \\
\end{array}$ & $\begin{array}{c}10-29 \\
11-200 \text { to } 205 \\
12-37 \\
12-93 \text { to } 96\end{array}$ & 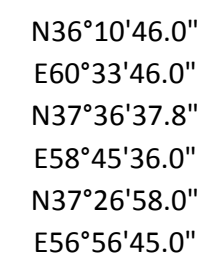 & $\begin{array}{l}\text { Limestone with chert } \\
\text { nodules and marl. } \\
\text { Flat channels }\end{array}$ & \\
\hline
\end{tabular}




\begin{tabular}{|c|c|c|c|c|c|c|c|c|}
\hline$\frac{\pi}{4}$ & $\begin{array}{l}\bar{O} \\
. \frac{0}{2} \\
2 \\
2\end{array}$ & \begin{tabular}{l}
\multicolumn{1}{|c}{} \\
운 \\
\end{tabular} & 品 & $\mathrm{fm}$ & Sample reference & $\begin{array}{l}\text { Sample } \\
\text { location }\end{array}$ & Lithology & Observed Nannofossils \\
\hline \multirow{13}{*}{ 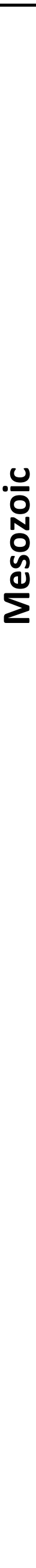 } & \multirow{3}{*}{ 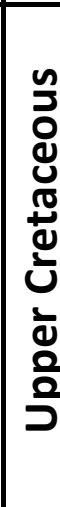 } & \multirow{2}{*}{ 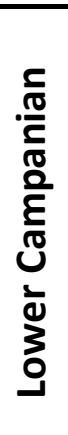 } & \multirow{2}{*}{\multicolumn{2}{|c|}{$\begin{array}{l}\frac{N}{0} \\
\frac{\pi}{0} \\
\frac{0}{4}\end{array}$}} & $\begin{array}{cc}10-26 \text { to } 28 & 10- \\
63,10-151, & 11- \\
251, & 11-252,12- \\
17 & \end{array}$ & $\begin{array}{c}\mathrm{N} 28^{\circ} 08^{\prime} 17.0^{\prime \prime} \\
\mathrm{E} 40^{\circ} 63^{\prime} 15.0^{\prime \prime} \\
\text { and } \\
\mathrm{N} 36^{\circ} 26^{\prime} 52.5^{\prime \prime} \\
\mathrm{E} 60^{\circ} 26^{\prime} 46.7^{\prime \prime}\end{array}$ & $\begin{array}{l}\text { Limestone with chert } \\
\text { nodules and marl. } \\
\text { Flat channels }\end{array}$ & $\begin{array}{l}\text { E. eximius } \\
\text { B. parca } \\
\text { R. anthophorus }\end{array}$ \\
\hline & & & & & $\begin{array}{l}10-20 \text { to } 25 \\
11-250,12-34 \\
12-120\end{array}$ & 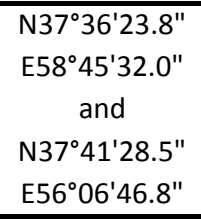 & $\begin{array}{l}\text { Limestone with chert } \\
\text { nodules and marl. } \\
\text { Flat channels. }\end{array}$ & $\begin{array}{l}\text { M. purcatus } \\
\text { R. anthophorus } \\
\text { E. eximius }\end{array}$ \\
\hline & & \multicolumn{7}{|c|}{ Turonian, Coniacien and L. Santonian : HIATUS } \\
\hline & \multirow{6}{*}{ 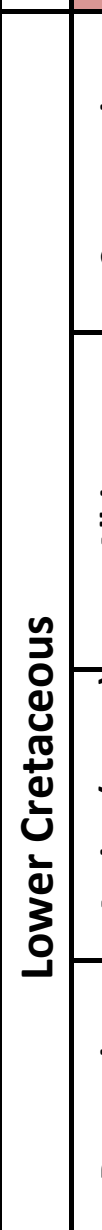 } & 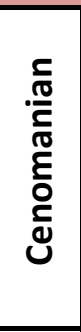 & & 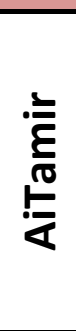 & \begin{tabular}{|c|}
$10-13$ to 19 \\
$11-351$ to 361 \\
$11-369$ to 373 \\
$11-376,11-377$ \\
$12-65$ to 67
\end{tabular} & 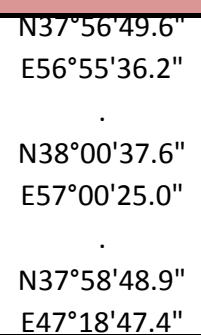 & $\begin{array}{c}\text { grainstone, } \\
\text { sandstone siltstone or } \\
\text { dark, brownish } \\
\text { silstone claystone }\end{array}$ & $\begin{array}{l}\text { Barren of nannofossils } \\
\text { with flute channels and } \\
\text { wood on the base }\end{array}$ \\
\hline & & \multirow[t]{2}{*}{$\frac{\frac{c}{0}}{\frac{.0}{0}}$} & \multirow{2}{*}{\multicolumn{2}{|c|}{ 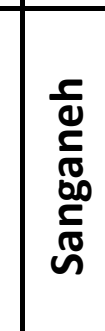 }} & $\begin{array}{l}11-246 \text { to } 248 \\
12-148 \text { à } 150\end{array}$ & $\begin{array}{l}\text { N37º56'56.7" } \\
\text { E55 } 55^{\circ} 39^{\prime} 40.1^{\prime \prime}\end{array}$ & $\begin{array}{c}\text { fine grained } \\
\text { sandstones, marl, } \\
\text { dark sandstone, } \\
\text { claystone with } \\
\text { concretions } \\
\end{array}$ & $\begin{array}{l}\text { E. turriseiffelii } \\
\text { P. cretacea } \\
\text { P. albianus } \\
\text { N. pragilis }\end{array}$ \\
\hline & & & & & \multicolumn{4}{|c|}{ Gap of barren of nannofossils } \\
\hline & & 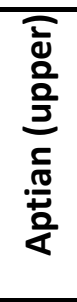 & \multirow{2}{*}{\multicolumn{2}{|c|}{ 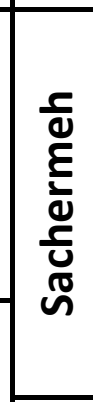 }} & \multirow{2}{*}{\begin{tabular}{|c|}
$10-9,10-96$ to 98 \\
$11-244$ to 245, \\
$11-303$ to 305 \\
$11-349$ \\
\\
$10-2$ to $7,11-297$ to $29 ;$ \\
$11-344$ to 348 11-362 \\
to 365 \\
\end{tabular}} & & \multirow[t]{2}{*}{$\begin{array}{c}\text { siltstone, marl with } \\
\text { lumachelles, beds of } \\
\text { thin limestone, beds } \\
\text { orbitoids }\end{array}$} & $\begin{array}{l}\text { E. floralis } \\
\text { R. angustus } \\
\text { N. wasseli } \\
\text { N. quadriangulus } \\
\text { N. carniolensis latus }\end{array}$ \\
\hline & & \multirow{2}{*}{ 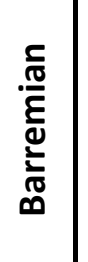 } & & & & 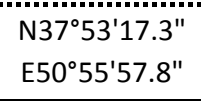 & & \multirow{2}{*}{$\begin{array}{l}\text { N. colomii } \\
\text { N. circularis } \\
\text { N. steinmossii } \\
\text { G. margerellii }\end{array}$} \\
\hline & & & & 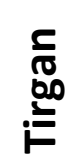 & $\begin{array}{l}10-84 \text { to } 90 \\
11-241 \text { to } 243\end{array}$ & $\begin{array}{l}\mathrm{N} 36^{\circ} 00^{\prime} 40.2^{\prime \prime} \\
\mathrm{E} 60^{\circ} 55^{\prime} 32.6^{\prime \prime}\end{array}$ & $\begin{array}{l}\text { massive limestones } \\
\text { rich in orbitoid marl } \\
\text { intercalations }\end{array}$ & \\
\hline & & \multicolumn{7}{|c|}{ Valanginian- Hauterivian: Gap or not yet determined } \\
\hline & & $\begin{array}{l}\frac{\pi}{2} \\
. \frac{\pi}{2} \\
\frac{\pi}{2} \\
0 \\
0\end{array}$ & & 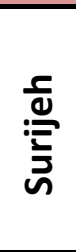 & $11-325$ to 328 & & $\begin{array}{l}\text { red continental } \\
\text { sandstone and } \\
\text { siltstone, lenses of } \\
\text { anhydrite } \\
\text { conglomerates }\end{array}$ & $\begin{array}{l}\text { P. bechnommi } \\
\text { G. deflondres } \\
\text { G. margerellii }\end{array}$ \\
\hline & $\begin{array}{l}\frac{\grave{2}}{2} \\
\frac{1}{d} \\
\frac{0}{2} \\
\frac{2}{2}\end{array}$ & 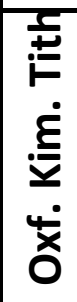 & & 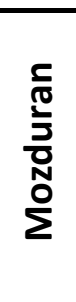 & & & $\begin{array}{c}\text { recifal limestones } \\
\text { bedded limestones } \\
\text { with marl sandstones } \\
\text { with conglomerates } \\
\text { in chorrels }\end{array}$ & $\begin{array}{l}\text { low diversified } \\
\text { assemblages no precise } \\
\text { age determination }\end{array}$ \\
\hline & 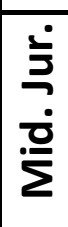 & 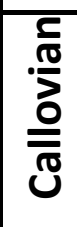 & & $\begin{array}{l}\frac{0}{0} \\
\frac{1}{0} \\
\frac{5}{5} \\
\frac{5}{0} \\
\frac{5}{U}\end{array}$ & $11-216$ to 222 & $\begin{array}{l}\text { N47º } 46^{\prime} 69.3^{\prime \prime} \\
\text { E41 } 37^{\prime} 85.8^{\prime \prime}\end{array}$ & siltstone marl & $\begin{array}{l}\text { C. deflassids } \\
\text { E. gallicus }\end{array}$ \\
\hline
\end{tabular}



